San Jose State University

SJSU ScholarWorks

Master's Theses

Master's Theses and Graduate Research

1995

\title{
Frequency distributions and linkage relationships of ten genetic markers in the Santa Clara County Vietnamese population
}

Lisa Marie Brewer

San Jose State University

Follow this and additional works at: https://scholarworks.sjsu.edu/etd_theses

\section{Recommended Citation}

Brewer, Lisa Marie, "Frequency distributions and linkage relationships of ten genetic markers in the Santa Clara County Vietnamese population" (1995). Master's Theses. 974.

DOI: https://doi.org/10.31979/etd.k4sd-4n7s

https://scholarworks.sjsu.edu/etd_theses/974

This Thesis is brought to you for free and open access by the Master's Theses and Graduate Research at SJSU ScholarWorks. It has been accepted for inclusion in Master's Theses by an authorized administrator of SJSU ScholarWorks. For more information, please contact scholarworks@sjsu.edu. 


\title{
FREQUENCY DISTRIBUTIONS AND LINKAGE
}

\section{RELATIONSHIPS OF TEN GENETIC MARKERS IN THE SANTA CLARA COUNTY VIETNAMESE POPULATION}

\author{
A Thesis \\ Presented to \\ The Faculty of the Department of Chemistry \\ San Jose State University
}

In Partial Fulfillment

of the Requirements for the Degree

Master of Science

by

Lisa Marie Brewer

May 1995 
UMI Number: 1374565

UMI Microform 1374565

Copyright 1995, by UMI Company. All rights reserved.

This microform edition is protected against unauthorized copying under Title 17, Onited States Code.

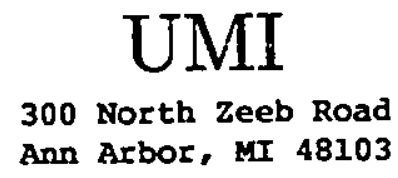




\section{APPROVED FOR THE DEPARTMENT OF CHEMISTRY}

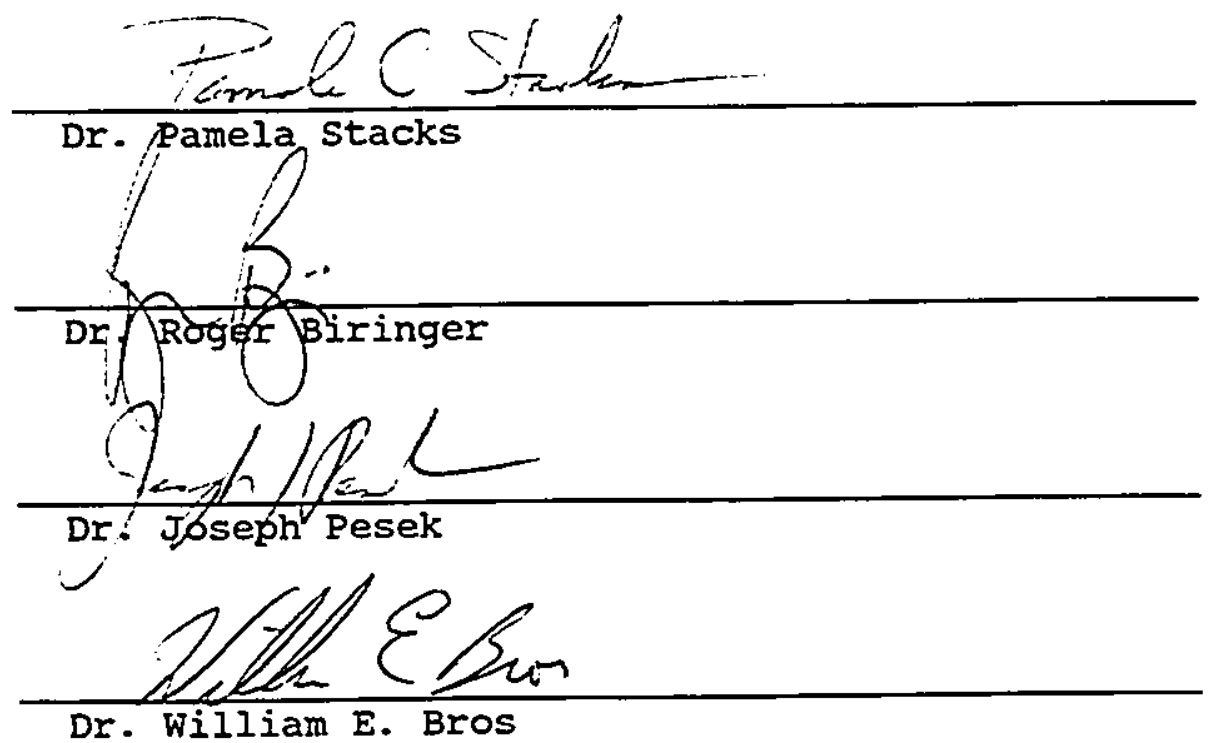

\section{APPROVED FOR THE UNIVERSITY}

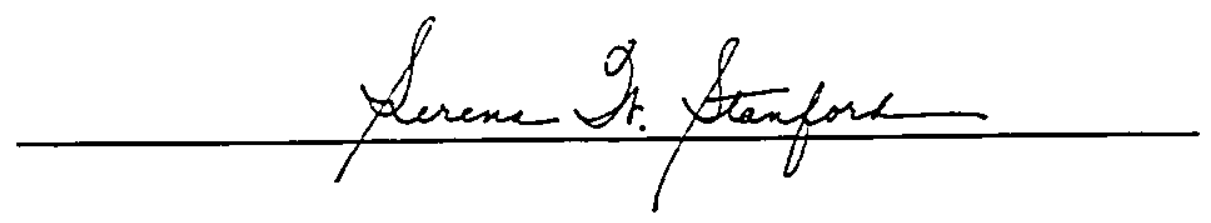


(1) 1995

Lisa Marie Brewer

ALI RIGHTS RESERVED 


\section{ABSTRACT}

\section{FREQUENCY DISTRIBUTIONS AND IINKAGE RELATIONSHIPS \\ OF TEN GENETIC MARRERS IN THE \\ SANTA CLARA COUNTY VIETNAMESE POPULATION}

by Lisa $M$. Brewer

Polymorphic proteins have traditionally been used as genetic markers to establish identity in human populations. The advent of PCR (polymerase chain reaction) based DNA testing methods have additionally allowed the use of DNA polymorphisms for this purpose. Identity testing is based on the determination of a genetic marker profile and a statistical interpretation based on the uniqueness of the profile in a population of interest. Statistical interpretation of a profile requires the independence of the genetic markers in accordance to Mendel's Law of Independent Assortment. In addition, statistical interpretation of genetic marker profiles require allelic frequency distribution data for relevant population groups.

This study establishes allelic frequency distributions for ten genetic markers in the Santa clara County vietnamese population. of ten markers studied, eight were determined to be polymorphic and met Hardy-Weinberg expectations. In addition, this study demorstrates the independence of six protein genetic markers and a DNA polymorphic marker. The independence of these loci validate the use of the product rule when estimating genetic marker profile match probability. 


\section{Acknowledgments}

I would like to express my gratitude to the following individuals whose contributions and support made this study possible: Dr. Pamela stacks, graduate advisor; Dr. Roger Biringer, Dr. Joseph Pesek and Dr. William E. Bros, committee nembers; Sean Walsh, Roche Mclecular Systems; Dr. Bruce Weir, North Carolina State University; Dr. Elisabeth Mailhot, Hoang Nguyen and Miranda Wong, Valley Medical Center: Officer Tom Pham, San Jose Police Department; Nancy Marte, Mark Moriyama, Doug Ridolfi, Lisa Skinner and Denise Wong, Criminalists at the Santa clara County Crime Laboratory; Benny Del Re and Grady Goldman, Director and Assistant Director of the Santa clara county crime Laboratory. 


\section{Table of Contents}

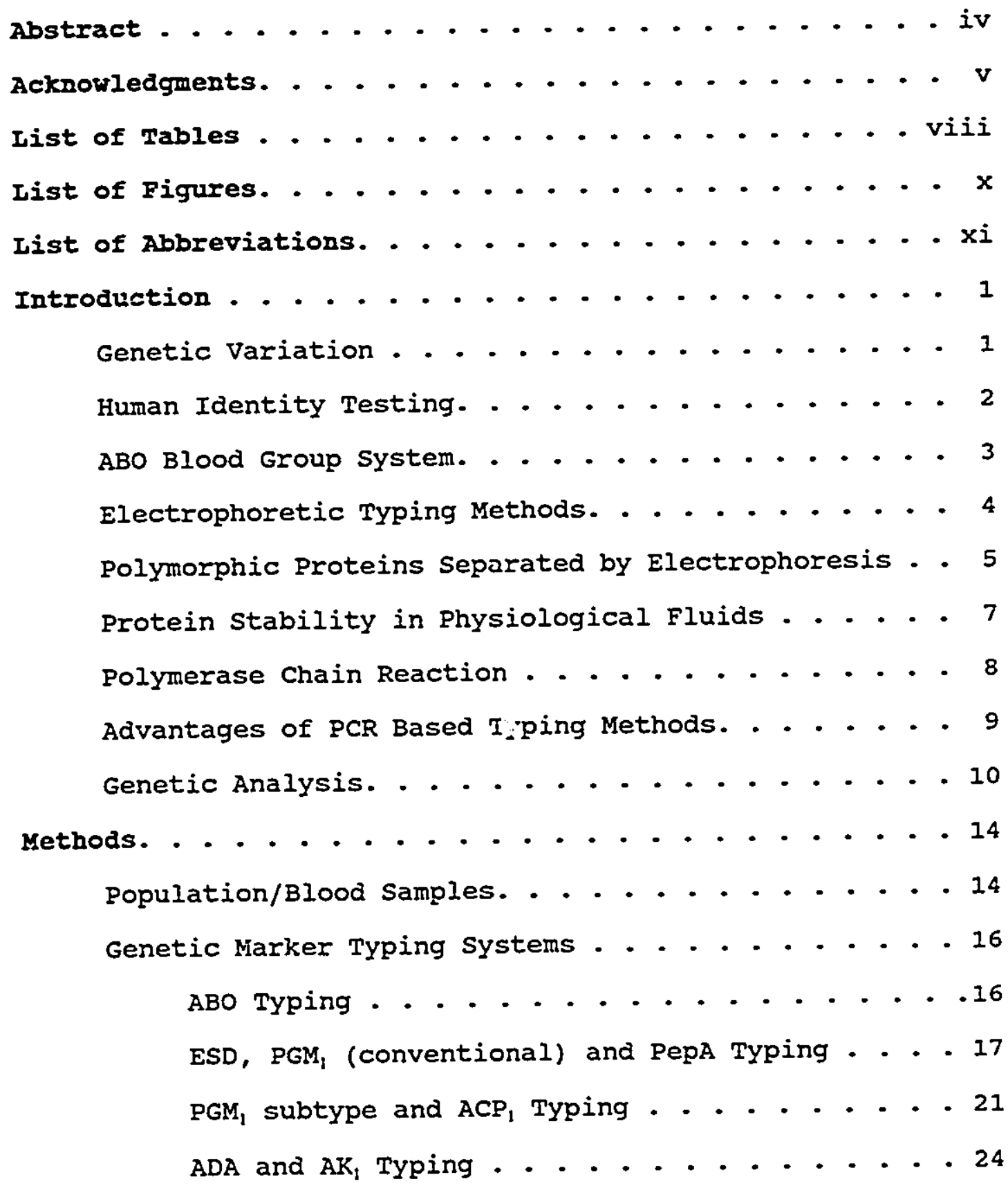


GC and TF Typing . . . . . . . . . . . 27

FIA DQQ TYPing . . . . . . . . . . . . 29

Quality Assurance . . . . . . . . . . . . . 33

Statistical Analysis. . . . . . . . . . . . 33

Allelic Frequency Determination. . . . . . 34

Locus Discrimination Power . . . . . . . . 35

Single Locus Tests . . . . . . . . . . 36

Two Locus Tests. . . . . . . . . . . 38

Significance of the p-value. . . . . . . . 38

Results. . . . . . . . . . . . . . . . . 40

Allelic Frequencies . . . . . . . . . . . 41

Loci Discrimination Power . . . . . . . . . 46

Allelic Frequency Comparison of Various Populations - 47

single Locus Tests. . . . . . . . . . . . 51

Two Iocus Tests. . . . . . . . . . . . 53

conclusions. . . . . . . . . . . . . . . . 56

Loci Discrimination Power . . . . . . . . . 57

Santa clara county Vietnamese Population Compared to Vietnam Populations . . . . . . . . . . 58

Comparison of the Major Population Groups in Santa Clara county. . . . . . . . . . . . . . . 58

Independence Testing. . . . . . . . . . . 59

References . . . . . . . . . . . . . . 63

vii 


\section{List of Tables}

Table 1 Persistence of Some Genetic Markers in Physiological Fluids . . . . . . . . . 8

Table 2 Polymorphic loci used in human identity testing. . . . . . . . . . . . . . 13

rable $3 a$ ABO forward typing, determines antigens present. . . . . . . . . . . . . 16

Table $3 b$ ABO reverse typing, determines antibodies present. . . . . . . . . . . . . 16

Table 4 Restriction patterns expected with Fok I and Rsa I digests of the DQAI amplified PCR product. . . . . . . . . . . . . 32

Table 5a TF genotypes observed in the santa clara county Vietnamese population and a vietnam population . 37

Table 5b $R \times C$ contingency table and $X^{2}$ analysis of the Santa clara county vietnamese population and a vietnam population . . . . . . . . . . . . 37

Table 6 Number of samples with typing results $(n=135) \cdot 40$ Table 7a DQA1 locus genotypes observed in the Santa Clara County vietnamese population $(n=130) \cdot . \cdot . \cdot 42$ Table $7 b$ PGM locus genotypes observed in the santa clara County vietnamese population . . . . . . . 43 
Table 7C $A C P_{1}, A B O, T F, A D A, E S D$ and $G C$ genotypes observed in the santa clara county vietnamese population $(n=130)$. . . . . . . . . . . . . 44

Fable 8 Allelic frequency distributions for the Santa clara County vietnamese population $(n=130) \cdot . \cdot .45$

Table 9 Loci discrimination power $\left(P_{D}\right)$ for the Santa Clara County vietnamese population . . . . . . . 46

Table 10 observed genotypes in the santa clara county vietnamese and vietnam populations . . . . . 48

Table 11 Allele and phenotypic frequency distributions in the major population groups of Santa Clara county . . . . . . . . . . . . . 51

Table 12 Hardy-Weinberg Test Results. . . . . . . . 52

Table 13 Tests for association at pairs of loci $(n=130) \cdot 55$ 


\section{List of Figures}

Figure 1 Diagram of agarose gel electrophoretic banding patterns of ESD genotypes. . . . . . . . 18

Figure 2 Diagram of agarose gel electrophoretic banding patterns of the PepA and $\mathrm{PGM}_{1}$ (conventional) genotypes. . . . . . . . . . . . . 20

Figure 3 Diagram of agarose gel electrophoretic banding patterns of the $\mathrm{ACP}_{1}$ genotypes . . . . . . . 22

Figure 4 Diagram of agarose gel electrophoretic banding patterns of the $\mathrm{PGM}_{1}$ subtype genotypes . . . . 23

Figure 5 Diagram of the agarose gel electrophoretic banding patterns of the $\mathrm{ADA}$ and $\mathrm{AK}_{1}$ genotypes. . . . . 26

Figure 6 Diagram of agarose gel electrophoretic banding patterns of the GC and TF genotypes. . . . . . 28

Figure 7a DQA1 allelic frequency distributions in the major population groups of Santa clara county. . . . 49 Figure $7 b \mathrm{PGM}_{1}$ allelic frequency distributions in the major population groups of Santa clara county. . . . 50 


\section{List of Abbreviations}

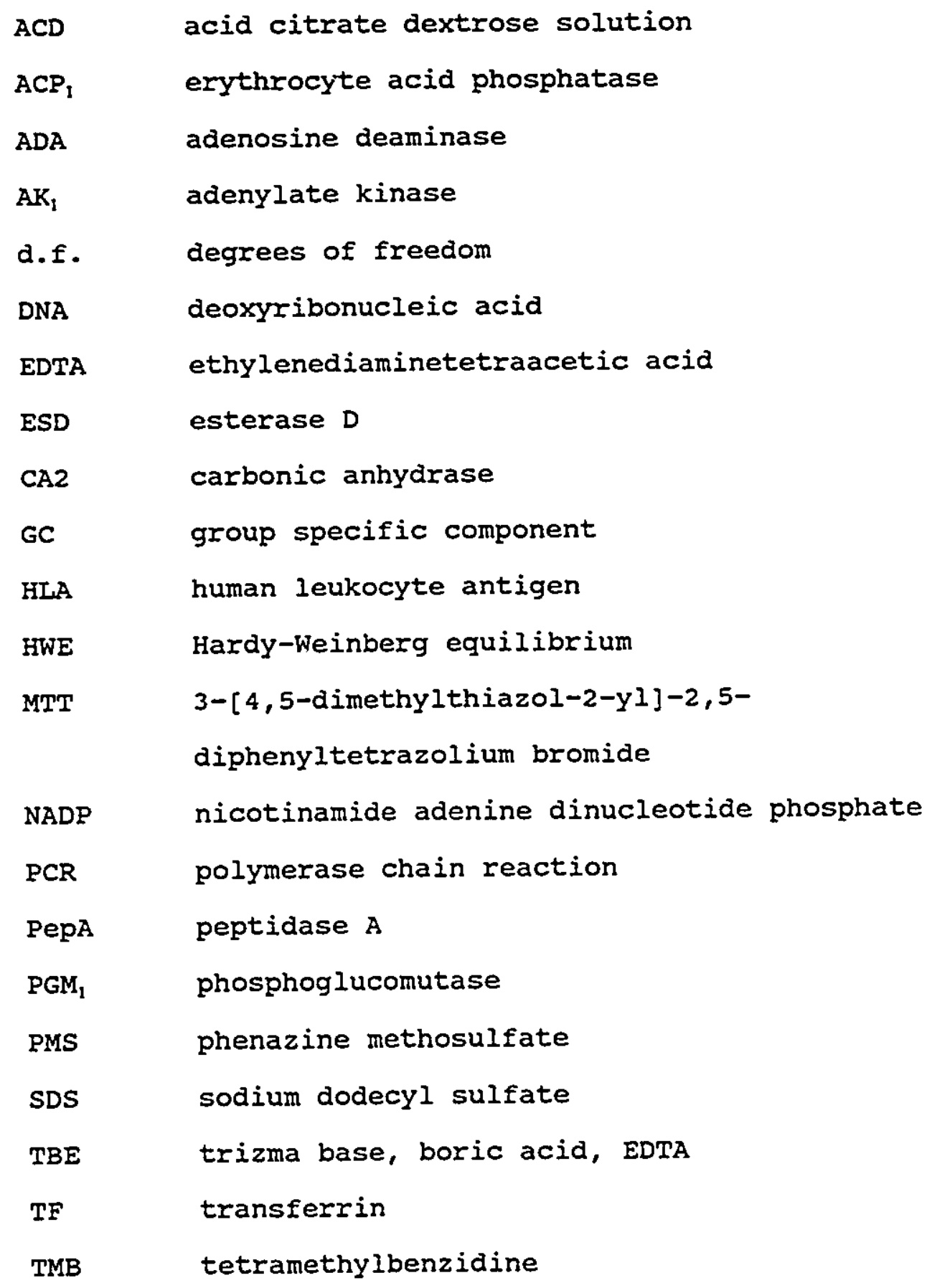




\section{Introduction}

Polymorphic proteins have traditionally been used as genetic markers to establish identity in human populations. The advent of PCR (polymerase chain reaction) based DNA testing methods have additionaily allowed the use of DNA polymorphisms for this purpose. Identity testing is based on the determination of a genetic marker profile and a statistical interpretation based on match probability or uniqueness of the profile in a population of interest. Statistical interpretation of a profile requires the independence of the genetic markers in accordance to Mendel's Law of Independent Assortment. The purpose of this study is to examine both protein and DNA based genetic markers and to assess the independence of these markers in a particular population. Included is an overview of the basic principles utilized in human identity testing: genetics, immunology, biochemistry, molecular biology and population statistics.

\section{Genetic Variation}

Genetic variation, or polymorphism, provides the basis for using genetically determined characteristics as markers in the human population (Gaensslen, 1985). A polymorphic genetic marker is defined as a multiallelic locus inherited in a 
manner based on Mandelian genetics. The allelic frequencies of these markers are known to vary in human populations. Because of these factors, genetic variation studies are used in ancestral studies (Hartl, 1988; Darlu and Cavalli-Sforza, 1985), the diagnosis of disease states (Hernandez, Elston and Ward, 1990; Hartl, 1983; Nakamura et al., 1987) and human identity testing (Gaensslen, 1985; Gaensslen et al., 1987a; $1987 \mathrm{~b} ; 1987 \mathrm{c})$.

\section{Human Identity Testing}

Human identity testing is an applied science that utilizes basic principles in genetics, immunology, biochemistry, molecular biology and statistics in the individualization of blood and physiological fluids. Individual identification is important in resolving paternity disputes, providing evidence associated with violent crimes and as an aid in the identification of mass disaster victims and wartime casualties.

Identity testing is based on the determination of a genetic marker profile and a statistical interpretation based on the probability or uniqueness of the profile in a population of interest. To achieve sufficient discrimination 
power' for identity testing, more than one polymorphic marker must be tested. This may include a combination of protein markers as well as DNA polymorphisms. Theoretically, if enough genetic markers are tested, an absolute identification may be made. Practically, the number of markers currently available are not sufficient for this level of identification. However, with the addition of new DNA polymorphisms, this may become a reality.

\section{ABO Blood Group System}

In 1901, Lansteiner recognized that not all human blood is the same, developing what is now known as the ABO blood group system. The ABO system is based on red cell antigens that determine the $A B O$ type, as well as antibodies that are specific to the blood group antigens the red cells lack. ABO blood types are determined using specific antigen-antibody reactions known as agglutination. By using a series of specific $A B O$ antibodies and testing a blood sample against each one, the ABO type can be determined (DeForest et al., 1983) .

\footnotetext{
'Discrimination power refers to the ability of a genetic marker to distinguish between two individuals in a population (individualization).
} 


\section{Electrophoretic Typing Methods}

Most of the genetic markers used for individualization are isolated by electrophoresis (Budowle and Davidson, 1984). In general, the protein structure associated with each allele in a genetic marker system has enough sequence variation to exhibit a different electrophoretic mobility. Therefore, electrophoretic separation is an effective method for determining genetic variation in a number of genetic markers that includes red blood cell enzymes and serum proteins.

Electrophoresis is a technique that separates proteins based on size, shape and net charge differences. A bloodstain is placed in a support medium, such as agarose, to which an electric current is applied. Proteins in the stain will migrate to the pole opposite to their own charge. Under specific parameters, such as buffer $\mathrm{pH}$ and time, the proteins will separate due to different migration rates (DeForest et al., 1983). When separation is complete, the colorless proteins can be visualized using assays based on enzymatic activity or other properties of the protein. Development is therefore dependent upon retention of the protein structure in the sample examined.

Due to the limited sample size encountered in physiological fluid evidence stains, electrophoretic techniques have been developed that allow the simultaneous detection of two or more genetic marker systems from one 
electrophoresis plate. These multisystem plates allow for more information to be obtained from a limited amount of stain material and are routinely used in the forensic laboratory (Wraxall and Stolorow, 1986; Divall, 1985; Hulen, 1984).

\section{Polymorphic Proteins Separated by Electrophoresis}

Polymorphic proteins detected by electrophoresis include red blood cell enzymes and serum proteins. The polymorphic proteins described below are well established as robust markers suitable for characterization of physiological fluid stains.

Phosphoglucomutase $\left(\mathrm{PGM}_{1}\right)$ catalyzes the reversible conversion of glucose-I-phosphate and glucose-6-phosphate with glucose-1,6-diphosphate being required as a cofactor. $\mathrm{PGM}_{1}$ is present in most tissues and bady fluids, including red blood cells, semen and vaginal fluid. There are four alleles (1, $1+, 2-, 2+$ ) resulting in ten possible genotypes (Gaensslen, 1983; Harris and Hopkinson, 1976). $P \mathrm{FM}_{1}$ is located on chromosome 1 (Mckusick, 1980).

Esterase D (ESD) is a non-specific esterase which indicates its physiological substrate is not known, therefore its exact metabolic role is unknown. It appears to be more active with esters of low molecular weight fatty acids (i.e., acetates and butyrates). ESD is present in most tissues, including red blood cells. There are two common alleles $(1,2)$ 
resulting in three possible genotypes (Gaensslen, 1983; Harris and Hopkinson, 1976). ESD is located on chromosome 13 (McKusick, 1980).

Erythrocyte acid phosphatase ( $A C P_{1}$ or EAP), an orthophosphoric monoester phosphohydrolase, is found in red blood cells. There are three common alleles $(A, B, C)$, resulting in six possible genotypes (Gaensslen, 1983; Harris and Hopkinson, 1976). ACP, is located on chromosome 2 (McKusick, 1980).

Peptidase A (PepA) is an exopeptidase that catalyzes the hydrolosis of a variety of dipeptides. PepA is present in most tissues, including red blood cells, semen and vaginal fluid. There are two common alleles $(1,2)$ resulting in three possible genotypes. Allele 2 is frequently found in Black populations and is exceedingly rare in non-black populations (Gaensslen, 1983; Harris and ilopkinson, 1976). PepA is located on chromosome 18 (McKusick, 1980).

Adenosine deaminase (ADA) deaminates adenosine to produce inosine. ADA is present in most tissues, including red blood cells. There are two common alleles $(1,2)$ resulting in three possible genotypes (Gaensslen, 1983; Harris and Hopkinson, 1976). ADA is located on chromosome 20 (McKusick, 1980).

Adenylate Rinase $\left(A K_{1}\right)$, also known as myokinase, catalyzes the reversible conversion of ATP and AMP to ADP. $\mathrm{AK}_{\mathrm{l}}$ is present in most tissues, including the red blood cells. 
There are two common alleles $(1,2)$, resulting in 3 possible genotypes. $A_{1} I$ and $A K_{1}$ 2-1 are frequently observed genotypes while the $\mathrm{AK}_{1} 2$ genotype is rare (Gaensslen, 1983; Harris and Hopkins, 1976). $\mathrm{AK}_{1}$ is located on chromosome 9 (McKusick, 1980).

Group specific component (GC) is a polymorphic serum protein that binds vitamin D. There are two common alleles $(1,2)$, resulting in three possible genotypes (Gaensslen, 1983). GC is located on chromosome 4 (McKusick, 1980).

Transferrin (TF) is a polymorphic serum protein that binds iron. There are three common genotypes (C, CB, CD) (Gaensslen, 1983). TF is located on chromosome 3 (Mckusick, 1980).

\section{Protein Stability in Physiological Fluids}

The persistence of protein activity in physiological fluids is necessary for the individualization of physiological fluid evidence (dried or liquid) commonly associated with violent crimes. The relative stability of protein genetic markers based on experimental and casework studies are shown in Table 1 (Gaensslen, 1985; Denault et al., 1980). In general, the ability to detect protein genetic markers in physiological fluids decreases with time, storage temperature, humidity (dried stains) and chemical environment (liquid preservative). 
Table 1: Persistence of Some Genetic Markers in Physiological Fluids*

\begin{tabular}{|c|c|}
\hline Genetic Marker & Persistence \\
\hline$A B O$ & $2-34$ years \\
\hline$A K_{1}$ & $12-52$ weeks \\
\hline PGM & $4-26$ weeks \\
\hline$A D A$ & $2-22$ weeks \\
\hline$A C P_{1}$ & $1-13$ weeks \\
\hline PepA & $4-8$ weeks \\
\hline ESD & $2-4$ weeks \\
\hline \#Source: Gaensslen, 1985; Denault et al., 1980
\end{tabular}

\section{Polymerase Chain Reaction}

Polymerase chain reaction ( $P C R$ ) is an in vitro method for the primer directed amplification of a specific DNA sequence. Two oligonucleotide primers ${ }^{2}$ that flank the specific DNA sequence of interest are extended by the thermally stable DNA polymerase, Thermus aquaticus (Taq), in an automated series of heating and cooling cycles. This process generates millions of copies of a specific DNA sequence, facilitating the use of non-radioisotopic detection methods. Polymorphic DNA sequences typed using PCR based testing include the following loci: HLA DQ $\alpha, D 1580$, low density lipoprotein receptor,

${ }^{2}$ Oligonucleotide primers are single stranded DNA molecules of approximately 20 nucleotide units in length that serve as a growing point for the synthesis of a new strand of DNA along a complementary template strand (Cetus, 1990). 
glycophorin A, hemoglobin G gamma globin and group specific component (Herrin, Fildes and Reynolds, 1994; Comey et al., 1994) .

The DQQ locus is an HLA (Human Leukocyte Antigen) Class II polymorphic gene located on chromosome 6 (McKusick). Each HIA Class II protein is composed of two units: $\alpha$ and $\beta$. The DQ $\alpha$ locus encodes the $\alpha$ subunit of the protein. There are eight alleles $(1.1,1.2,1.3,2,3,4.1,4.2,4.3)$ which determine 36 possible genotypes. The sequence variations that determine these alleles are located in a $242 \mathrm{bp}$ region (239 bp for alleles 2 and 4 ) in the second exon of the $D Q \alpha$ gene (Cetus, 1990).

\section{Advantages of PCR Based Typing Methods}

Advantages of PCR based testing methods for individual identification include sensitivity and the ability to type degraded DNA samples. Typically, less than $1 \mathrm{ng}$ of DNA is required for analysis which makes DNA typing of single hairs (Higuchi et al., 1988), extremely small biological stains and bone fragments (Hochmeister et al., 1991) possible. Even the most degraded DNA samples, such as ancient remains (Paabo, 1989), Civil war bone (Fisher et al., 1993) and 10-15 year old evidentiary samples (Reynolds et al., 1991) have been successfully amplified. Amplification of degraded DNA samples is possible provided enough full length target sequence is 
present (Reynolds et al., 1989).

\section{Genetic Analysis}

Statistical interpretation of genetic marker typing profiles require population studies of different racial or ethnic groups in each genetic marker system (Ad Hoc Committee on Individual Identification by DNA Analysis, 1990). These studies establish genotypic frequencies of polymorphic loci in various population groups. Single locus frequencies are determined by the Hardy-Weinberg equation. This equation is an algebraic relationship that allows the calculation of expected genotypic frequencies from the observed genotypes. A population is considered to be in Hardy-Weinberg equilibrium (ITE) when the observed genotypes at a locus do not differ significantly from the expected genotypes. Typically, a genetic marker inherited in a manner following Mendelian genetics is found to be in Hardy-Weinberg equilibrium (Cavalli-Sforza and Bodmer, 1971).

The significance of a genetic profile is expressed in terms of probability. This is accomplished by determining the frequency of occurrence for the particular combination of genotypes in the profile. ${ }^{3}$ The frequency of occurrence is

${ }^{3}$ The following is an example of a genetic profile and the frequency of occurrence in a Caucasian population: 
simply the product of the single locus genotype frequencies, provided each locus is inherited independently. ${ }^{4}$ Independence, or linkage equilibrium, is expected for genetic markers located on different chromosomes in accordance with Mendel's Law of Independent Assortment. Empirical studies demonstrate the independence of protein genetic markers currently used in human identity testing (Hernandez, Elston and ward, 1990). The DQ $\alpha$ locus, a DNA polymorphic marker, is assumed to be in linkage equilibrium with these markers based upon chromosome location (Table 2) and a preliminary study of an Cakland Black population which tests the $D Q \alpha$ locus and four protein markers (Weir, 1994a).

Deviations from linkage equilibrium occur mainly when genes at different loci on the same chromosome segregate

\begin{tabular}{|c|c|}
\hline $\begin{array}{c}\text { Genetic Marker and } \\
\text { Dype }\end{array}$ & $\begin{array}{c}\text { Frequency of Type } \\
\text { (Caucasian) }\end{array}$ \\
\hline ABO type 0 & 0.48 \\
\hline PGM type 1+1- & 0.38 \\
\hline ESD type 1 & 0.79 \\
\hline EAP type BA & 0.42 \\
\hline
\end{tabular}

The percent of the population expected to have this combination of types is calculated by multiplying the population frequency of each type: $(0.48)(0.38)(0.79)(0.42) \times 100 \%=3 \%$.

${ }^{4}$ Based on the product rule which states that the probability of two independent events occurring simultaneously is the product of each of their respective probabilities. 
together. This type of association, known as linkage disequilibrium, has been observed in the HLA region of chromosome 6. Associations have been noted between alleles of Class I HLA-A and B loci and class II HLA DR and DQ Ioci. The extent of the linkage disequilibrium and the alleles involved vary between populations. To date, this HLA Iinkage disequilibrium has been studied in conjunction with HLA types and disease associations (Begovich et al., 1992; Newall, 1985).

In summary, probability calculations require genetic marker frequency data for various human populations. Extensive population frequency data are available for many protein genetic markers (Mourant et al., 1976), while frequency data for DNA polymorphisms are limited. The paucity of DNA polymorphism data is due to the recent application of DNA testing methods for individual identification. In terms of identity testing, the Vietnamese community has become a relevant population in the United States. To date, there are few published surveys of protein polymorphisms within the native vietnam population (Mourant et al., 1976) while there are no published surveys of protein or DNA polymorphisms in the Vietnamese-American population.

This study examines various protein genetic markers and the HLA $D Q \alpha$ locus in the Santa clara county Vietnamese population. The allelic frequency distribution of these 
genetic markers has been tested to determine if they meet Hardy-Weinberg expectations and are in linkage equilibrium. Finally, the data is compared to published surveys to determine if the frequency distribution of the local immigrant population is consistent with the native country population.

Table 2: Polymorphic loci used in human identity testing*

\begin{tabular}{|c|c|c|c|c|}
\hline $\begin{array}{l}\text { Chromosome } \\
\text { Iocation }\end{array}$ & Locus & Symbol & Alleles & Phenotypes \\
\hline $1 p 22.1$ & Phosphoglucomutase- 1 & $P G M_{1}$ & 4 & 10 \\
\hline $2 p 25$ & Acid phosphatase-1 & $\mathrm{ACP}_{1}$ & 3 & 6 \\
\hline $3 q 21$ & Transferrin & $\mathrm{TF}$ & 3 & 3 \\
\hline $4 q 12-q 13$ & $\begin{array}{l}\text { Group-specific } \\
\text { component }\end{array}$ & GC & 2 & 3 \\
\hline $6 \mathrm{p} 21.3$ & HLA DQ $\alpha$ & DQAI & 8 & 36 \\
\hline $9 q 34.1-q 34.2$ & ABO blood group & ABO & 3 & 4 \\
\hline $9 q 34.1$ & Adenylate kinase-1 & $\mathrm{AK}_{1}$ & 2 & 3 \\
\hline $13 q 14.1-q 14.2$ & Esterase D & ESD & 2 & 3 \\
\hline $18 q 23$ & Peptidase A & PepA & 2 & 3 \\
\hline $20 q 12-q 13.11$ & Adenosine deaminase & ADA & 2 & 3 \\
\hline
\end{tabular}

Source: Gaensslen, 1983; 0.0\%ien, 1993 


\section{Methods}

\section{Population/Blood Samples}

San Jose has the largest Vietnamese community of any aity within the United States with a population of 41,303 individuals (ACCIS, 1992). Santa Clara County, where San Jose is located, is ranked third nationwide in total vietnamese population (ACCIS, 1992; Bureau of the Census, 1993). Eighty six individuals were chosen from whole blood samples submitted to the Santa clara county crime Laboratory. These individuals represent victims and suspects of serious crimes occurring within Santa clara county. The racial group of these individuals was determined by field police officers and investigators. In many instances, a vietnamese interpreter was necessary for interviewing these individuals. Approximately thirty of these samples were chosen by surname only and with the assistance of a Vietnamese police officer, each individual was contacted to determine their racial group and to ensure no duplication or related individuals were included.

In adaition, forty nine whole blood samples were obtained from Vietnamese out-patients at Valley Medical Center located in San Jose, California. Patients were questioned by vietnamese laboratory personnel to determine their racial 
group and to ensure no duplication or related individuals were submitted.

Whole blood samples used in this study were collected and preserved in EDTA (ethylenediaminetetraacetic acid) or ACD (acid citrate dextrose solution) vacutainer blood tubes. Iiquid blood was used to determine the $A B O$ blood group type for each sample. A stain was prepared for each sample by dropping liquid whole blood onto a sterile cotton cloth. The stains were allowed to air dry, then stored frozen until genetic marker typing was performed on each sample.

\section{Genetic Marker Typing Systems}

\section{ABO Typing}

ABO blood group system is determined by antigen/antibody agglutination reactions. ABO typing of red blood cells (forward typing) determines the $A B O$ antigen(s) present. This is accomplished by testing whole blood with each of the antiseras (A, $B, H$ and $A B$ antibodies) and observing agglutination reactions (Gaensslen, 1983; DeForest et al., 1983).

$A B O$ typing of plasma determines the $A B O$ antibodies present. Determining $A B O$ antibodies in the plasma is an indirect method of determining the $\mathrm{ABO}$ antigens present on the red blood cell, thus termed reverse or back typing. ABO 
antibody typing is accomplished by testing plasma with each indicator cell reagent $(A, B, O)$ and observing agglutination reactions (Gaensslen, 1983; DeForest et al., 1983). Reverse typing is useful as a double check of the forward typing results.

Each sample was typed using forward and reverse typing. Forward and reverse typing results are interpreted as follows:

Table 3a: ABO forward typing, determines antigens present on red blood cells

\begin{tabular}{|c|c|c|c|c|}
\hline $\begin{array}{c}\text { Blood } \\
\text { Group }\end{array}$ & anti-A & anti-B & anti-H & anti-A,B \\
\hline \hline $\mathrm{A}$ & + & - & + or - & + \\
\hline $\mathrm{B}$ & - & + & + or - & + \\
\hline $\mathrm{AB}$ & + & + & + or - & + \\
\hline $\mathrm{O}$ & - & - & + & - \\
\hline
\end{tabular}

Table 3b: ABO reverse typing, determines antibodies present in plasma

\begin{tabular}{|c|c|c|c|c|}
\hline $\begin{array}{c}\text { Blood } \\
\text { Group }\end{array}$ & A cells & B Cells & o cells & $\begin{array}{c}\text { Antibodies } \\
\text { Present }\end{array}$ \\
\hline \hline A & - & + & - & anti-B \\
\hline$B$ & + & - & - & anti-A \\
\hline Ai & - & - & - & none \\
\hline 0 & + & + & - & anti-A, B \\
\hline
\end{tabular}

$(+)$ agglutination, $(-)$ no agglutination 


\section{ESD, PGM $_{1}$ (conventional) and PepA Typing}

ESD, $\mathrm{PGM}_{1}$ (conventional) and PepA are determined using a multienzyme system known as the Modified Group I system (Hulen, 1984; Wraxall and Stolorow, 1986). The electrophoresis of these isoenzymes is performed on a $1 \%$ agarose gel (0.08 electroendosmosis) in pH 7.4 gel buffer (1:15 dilution of tank buffer: $0.1 \mathrm{M}$ trizma base, $0.1 \mathrm{M}$ maleic acid, $0.01 \mathrm{M}$ magnesium chloride, $0.1 \mathrm{M}$ sodium hydroxide). Samples and controls are prepared by teasing approximately 1 cm threads from each bloodstain and soaked in a minimal volume of $0.05 \mathrm{M}$ dithiothreitol. The threads are then inserted into the gel approximately $3 \mathrm{~cm}$ from the cathodic edge of the plate. The voltage is set at $400 \mathrm{~V}$ for 2.5 hours at $5^{\circ} \mathrm{C}$.

Following electrophoresis, ESD must be developed prior to $\mathrm{PGM}_{1}$ and $\mathrm{PepA}$ in the area extending from the origin to the anode. ESD detection is based upon the catalytic removal of an acetate group from the non-fluorescent substrate, 4methylumbelliferyl acetate, producing the fluorescent compound, 4-methylumbelliferone (Harris and Hopkinson, 1976). A filter paper overlay soaked with reaction mixture that contains 4-methylumbelliferyl acetate dissolved in ESD reaction buffer $[0.05 \mathrm{M}$ sodium acetate at $\mathrm{pH} 6.5]$ is placed over the gel and allowed to incubate at room temperature for approximately 5 minutes; longer for weaker stains. The filter paper is removed and the fluorescent band patterns are 
observed using transmitted long wave ultraviolet light. Each ESD genotype has a characteristic band pattern (Figure 1).

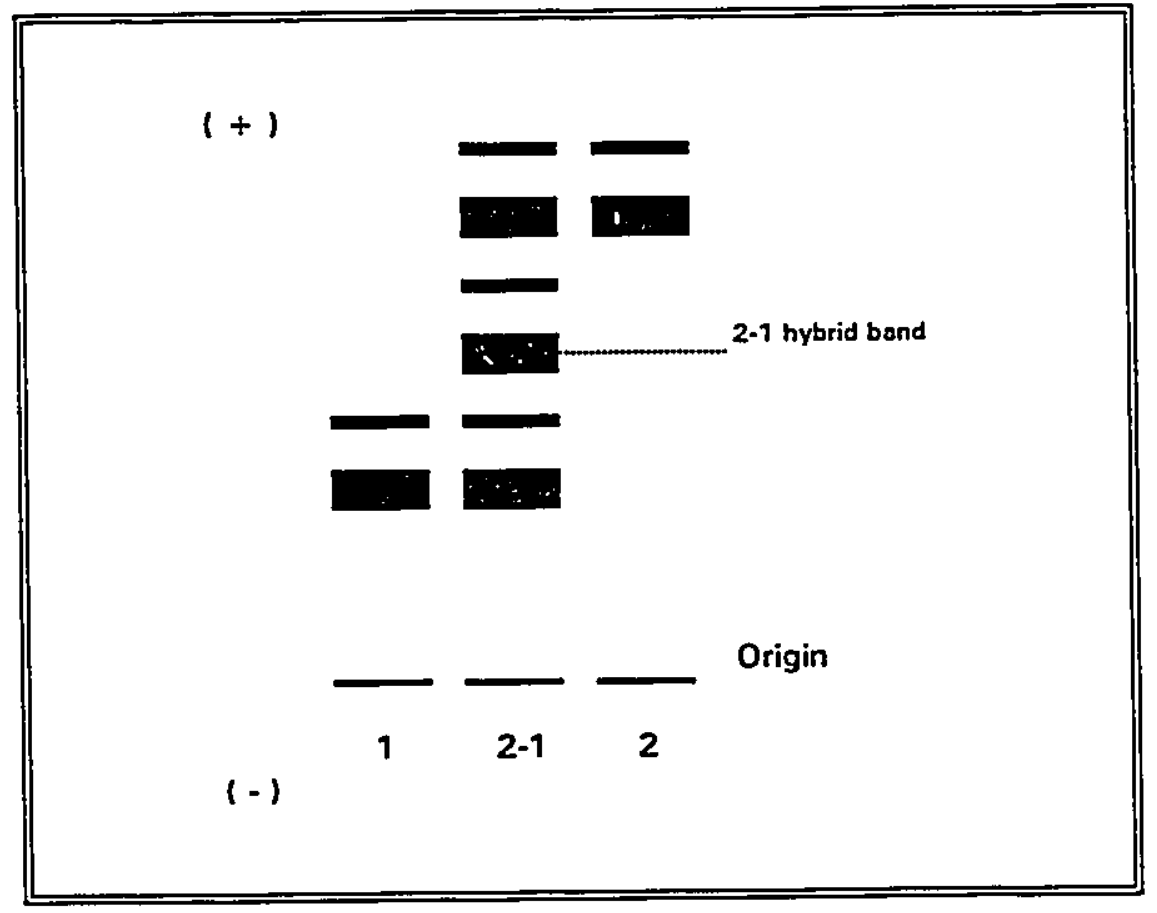

Figure 1 Diagram of agarose gel electrophoretic banding patterns of ESD genotypes. 
$\mathrm{PGM}_{1}$ and PepA may be developed simultaneously after ESD development. $\mathrm{PGM}_{1}$ and PepA detection mechanisms are characterized as enzyme coupled reactions linked to an electron-transfer dye system (Harris and Hopkinson, 1976).

$\mathrm{PGM}_{1}$ is developed using a $1-2 \%$ agarose overlay which contains the $\mathrm{PGM}_{1}$ reaction mixture [glucose-1-phosphate with 1\% glucose-1,6-diphosphate, nicotinamide adenine dinucleotide phosphate (NADP), phenazine methosulfate (PMS) or 8dimethylamino-2,3-benzophenoxazine (Medola Blue), 3-[4,5dimethylthiazol-2-yl]-2,5-diphenyltetrazolium bromide (MTT), ethylenediaminetetraacetic acid (EDTA), glucose-6-phosphate dehydrogenase] dissolved in $P G M$, reaction buffer [0.1 M trizma base, $0.02 \mathrm{M}$ magnesium chloride at $\mathrm{pH} 8.0 \mathrm{~J}$. The PGM, development overlay is poured over the gel, covering the area between the origin and the ESD 2-1 hybrid band (Figure 1).

PepA is developed using a 1-2\% agarose overlay which contains the PepA reaction mixture [L-valyl-L-leucine, L-amino acid oxidase, MTT, PMS] dissolved in PepA reaction buffer [0.1 M trizma base, $0.005 \mathrm{M}$ magnesium chloride at $\mathrm{pH} 8.0]$. The PepA development overlay is poured over the gel, covering the area between the ESD 2-1 hybrid band and the anodic edge.

The gel is incubated at $37^{\circ} \mathrm{C}$ over a period of time and typed when bands are of sufficient intensity to determine $P G M_{1}$ and PepA genotypes (Figure 2). $\mathrm{PGM}_{1}$ nominal allele types $(1,2)$ are detected with this system, thus the term $\mathrm{PGM}_{1}$ 
conventional typing system. By altering the electrophoresis system parameters, it was discovered that the $\mathrm{PGM}_{1}$ system actually has four alleles: the $\mathrm{PGM}_{1}$ nominal allele 1 could be typed as a $1+$ or 1 - while the $\mathrm{PGM}_{1}$ nominal allele 2 could be typed as a 2+ or 2- (Gaensslen, 1983). These PGM "subtypes" are detected using a $\mathrm{PGM}_{1}$ subtype system which is discussed below.

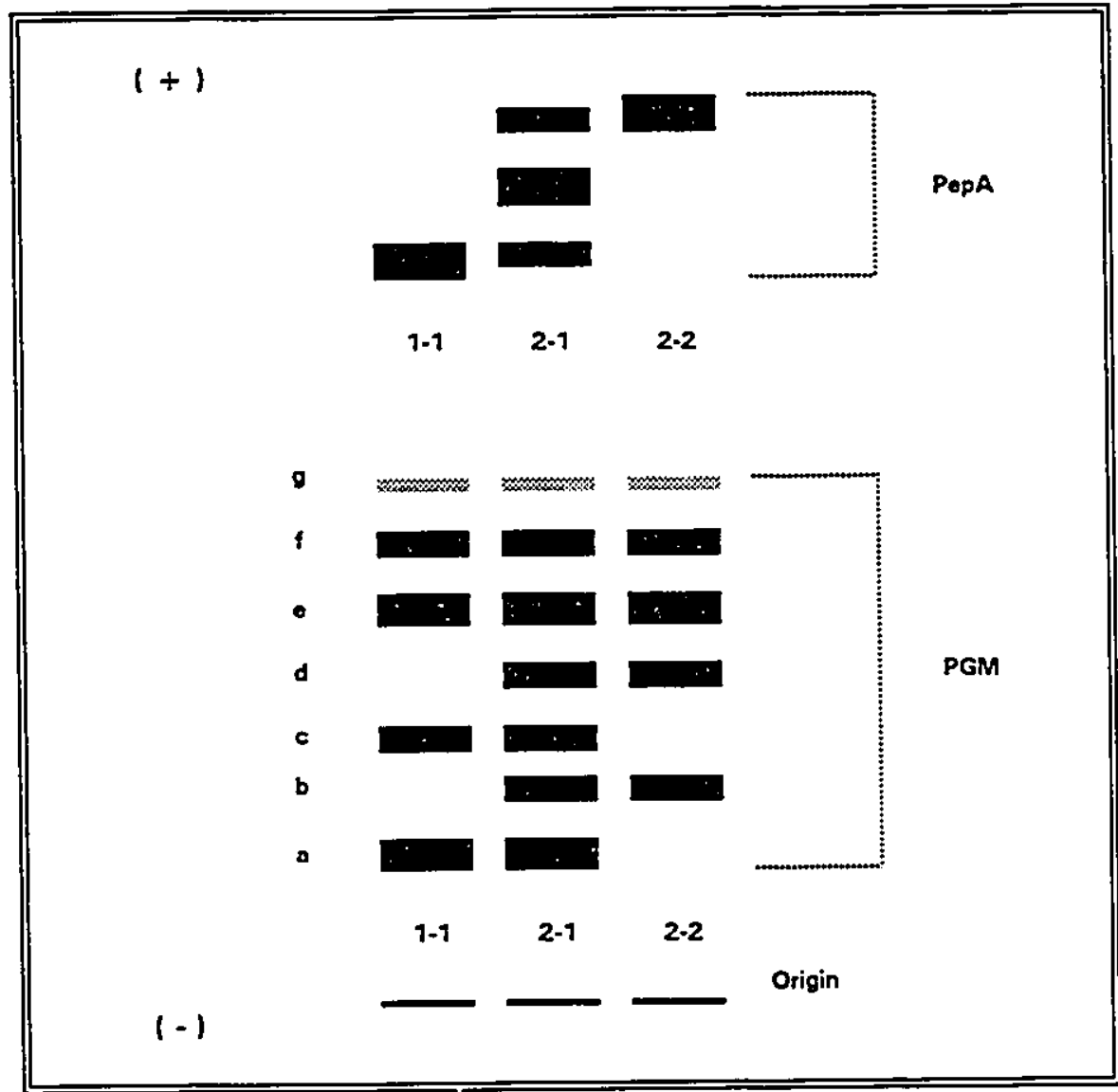

Figure 2 Diagram of agarose gel electrophoretic banding patterns of the PepA and $\mathrm{PGM}_{1}$ (conventional) genotypes. 


\section{$\mathrm{PGM}_{1}$ subtype and $\mathrm{ACP}_{1}$ Typing}

$\mathrm{FGM}_{1}$ subtypes and $A C P_{1}$ are simultaneously determined on a $1 \%$ agarose gel (Isogel, FMC Corp.) in a pH 5.5 gel buffer [0.0057 M sodium phosphate (dibasic), $0.0025 \mathrm{M}$ citric acid] (Wolson and Stuver, 1985). Samples and controls are prepared by teasing approximately $1 \mathrm{~cm}$ threads from each bloodstain and soaked in a minimal volume of $0.05 \mathrm{M}$ dithiothreitol. The threads are then inserted into the gel approximately $4 \mathrm{~cm}$ from the cathode edge of the plate. The voltage is set at $400 \mathrm{~V}$ for 4 hours at $5^{\circ} \mathrm{C}$ with a pH 5.5 tank buffer $[0.29 \mathrm{M}$ sodium phosphate (dibasic), $0.1 \mathrm{M}$ citric acid].

Following electrophoresis, $A C P$, must be developed first in the area extending from the origin toward the anode. $A C P_{1}$ detection is based on the catalytic removal of a phosphate group from the non-fluorescent substrate, 4-methylumbelliferyl phosphate, producing the fluorescent compound, 4methylumbelliferone (Harris and Hopkinson, 1976). A filter paper overlay soaked with a reaction mixture that contains 4methylumbellifery $I$ phosphate and $A C P_{1}$ reaction buffer $[0.05 \mathrm{M}$ citric acid, $0.1 \mathrm{M}$ sodium hydroxide at $\mathrm{pH} 5.0$ ] is placed over the gel and allowed to incubate at $37^{\circ} \mathrm{C}$ for approximately 30 minutes. The filter paper is removed and the fluorescent band patterns are observed using transmitted long wave ultraviolet light. Each $\mathrm{ACP}_{1}$ genotype has a characteristic band pattern (Figure 3). 


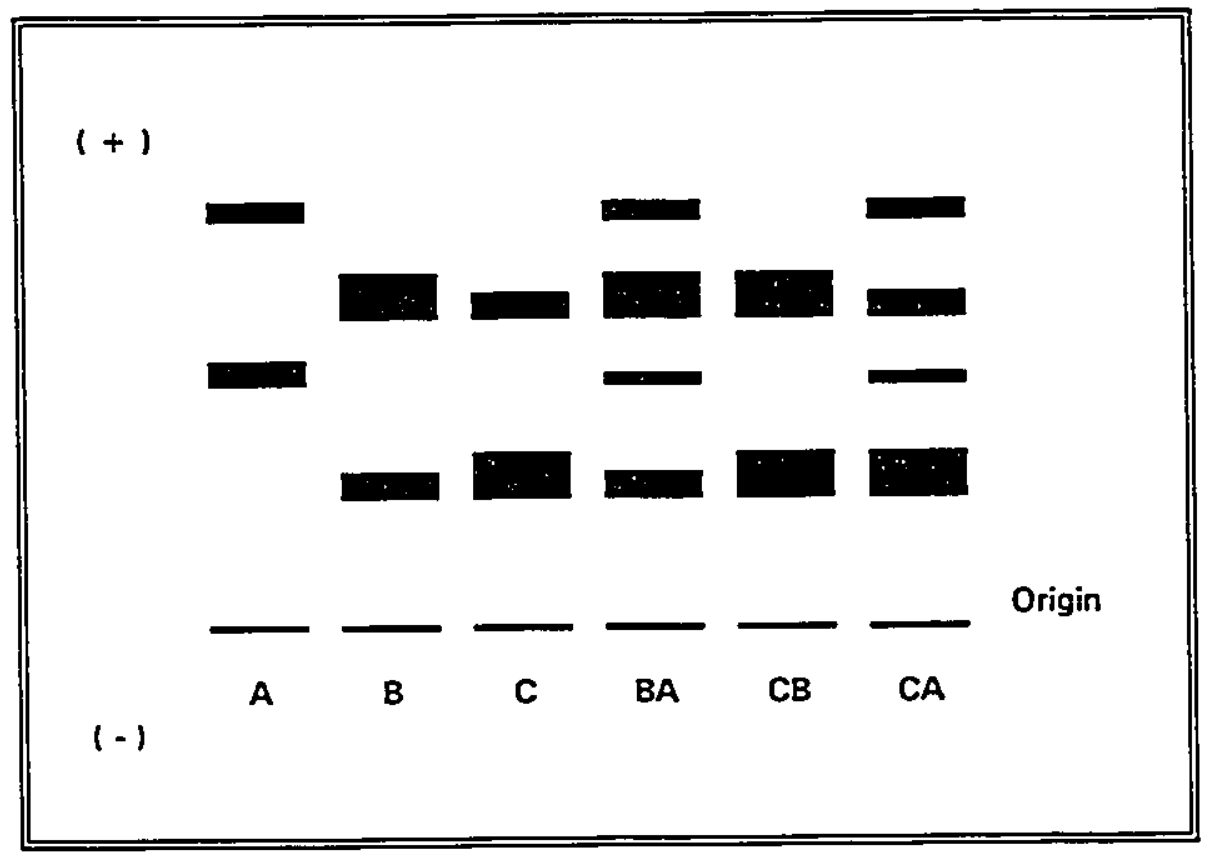

Figure 3 Diagram of agarose gel electrophoretic banding patterns of the $\mathrm{ACP}_{1}$ genotypes. 

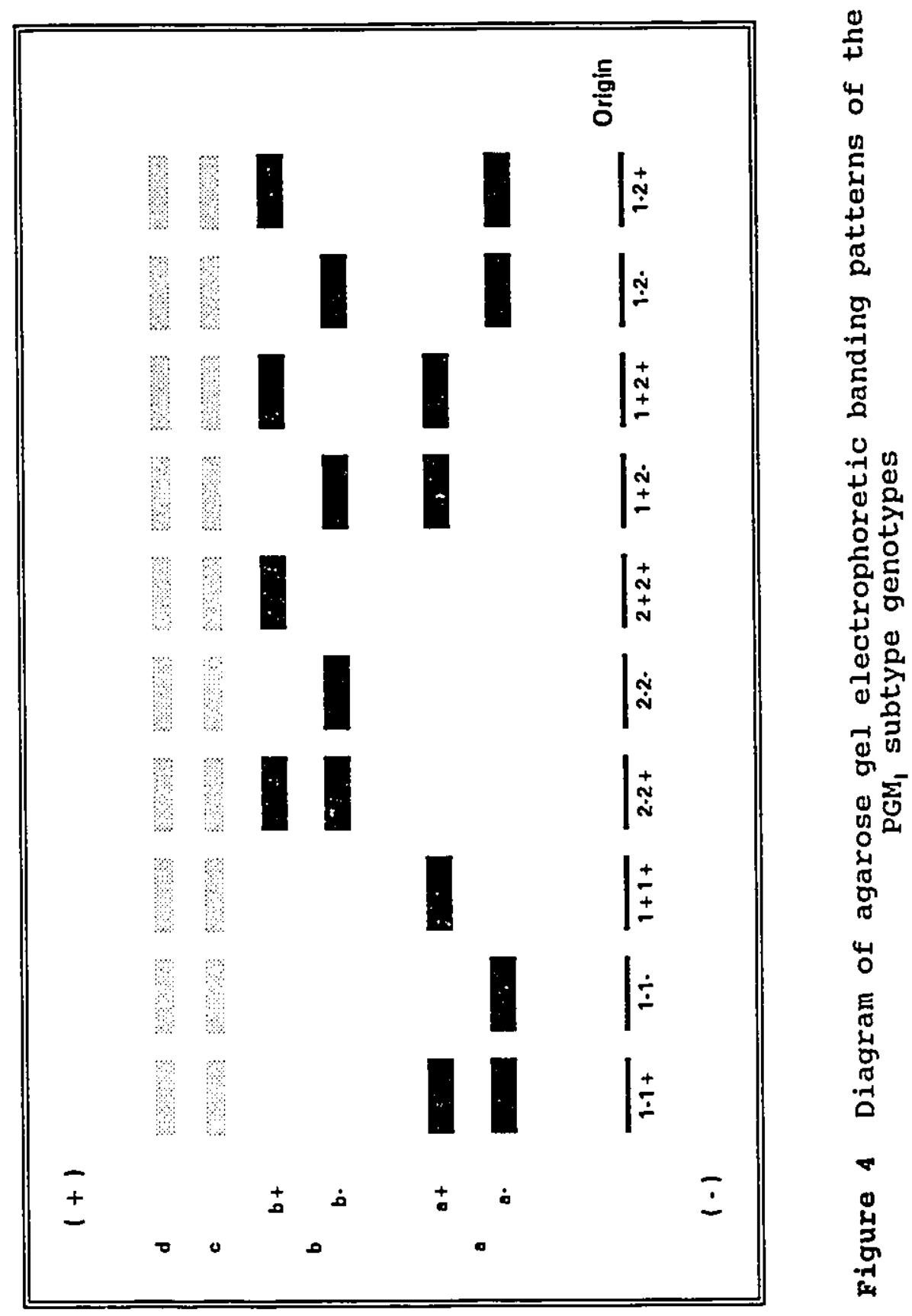
$\mathrm{PGM}_{1}$ subtype is developed after $\mathrm{ACP}_{1}$ development using a 1-2\% agarose overlay which contains the $\mathrm{PGM}_{1}$ reaction mixture (stated above) dissolved in a different $P G M_{1}$ reaction buffer [0.3 M trizma base, $0.02 \mathrm{M}$ magnesium chloride, $0.01 \mathrm{M}$ histidine at $\mathrm{pH}$ 8.0]. The PGM, development overlay is poured over the gel, covering the area between the origin and the anode (approximately $9 \mathrm{~cm}$ ). The gel is incubated at $37^{\circ} \mathrm{C}$ over a period of time and genotypes are determined when the bands are of sufficient intensity (Figure 4).

\section{ADA and $\mathrm{AK}_{1}$ Typing}

$A D A$ and $A K_{1}$ are simultaneously determined on a $1 \%$ agarose gel (Seakem LE, FMC Corp) in a pH 5.5 gel buffer $[0.0057 \mathrm{M}$ sodium phosphate (dibasic), $0.0025 \mathrm{M}$ citric acid]. Samples and controls are prepared by teasing approximately $1 \mathrm{~cm}$ threads from each bloodstain and soaked in a minimal volume of $0.05 \mathrm{M}$ dithiothreitol. The threads are then inserted into the gel approximately $10 \mathrm{~cm}$ from the cathodic edge of the plate. The voltage is set at $350 \mathrm{~V}$ for 90 minutes at $5^{\circ} \mathrm{C}$ with a pH 5.5 tank buffer $[0.29 \mathrm{M}$ sodium phosphate (dibasic), $0.1 \mathrm{M}$ citric acid].

$A D A$ and $A_{1}$ may be developed simultaneously following electrophoresis. $\mathrm{ADA}$ and $\mathrm{AK}_{\mathrm{i}}$ detection mechanisms are characterized as enzyme coupled reactions linked to an 
electron-transfer dye system (Harris and Hopkinson, 1976). ADA is developed using a 1-2\% agarose overlay which contains the ADA reaction mixture [adenosine, PMS or Medola Blue, MTT, xanthine oxidase, nucleoside phosphorylase] dissolved in ADA reaction buffer $[0.04 \mathrm{M}$ sodium phosphate (dibasic), $0.01 \mathrm{M}$ sodium phosphate (monobasic), at pH 7.5]. The ADA development overlay is poured over the gel, covering the area between the origin and the anode.

$\mathrm{AK}_{1}$ is developed using a $1-2 \%$ agarose overlay which contains the $A K_{1}$ reaction mixture [glucose, NADP, PMS, MTT, glucose-6phosphate dehydrogenase, hexokinase] dissolved in $\mathrm{AK}_{1}$ reaction buffer $[0.1 \mathrm{M}$ trizma base, $0.02 \mathrm{M}$ magnesium chloride at $\mathrm{pH}$ 8.03. The $\mathrm{AK}_{1}$ development overlay is poured over the gel, covering the area between the origin and the visible hemoglobin bands (cathodic edge). The gel is incubated at $37^{\circ} \mathrm{C}$ and typed when the bands are of sufficient intensity to determine $\mathrm{ADA}$ and $\mathrm{AK}_{1}$ genotypes (Figure 5). 


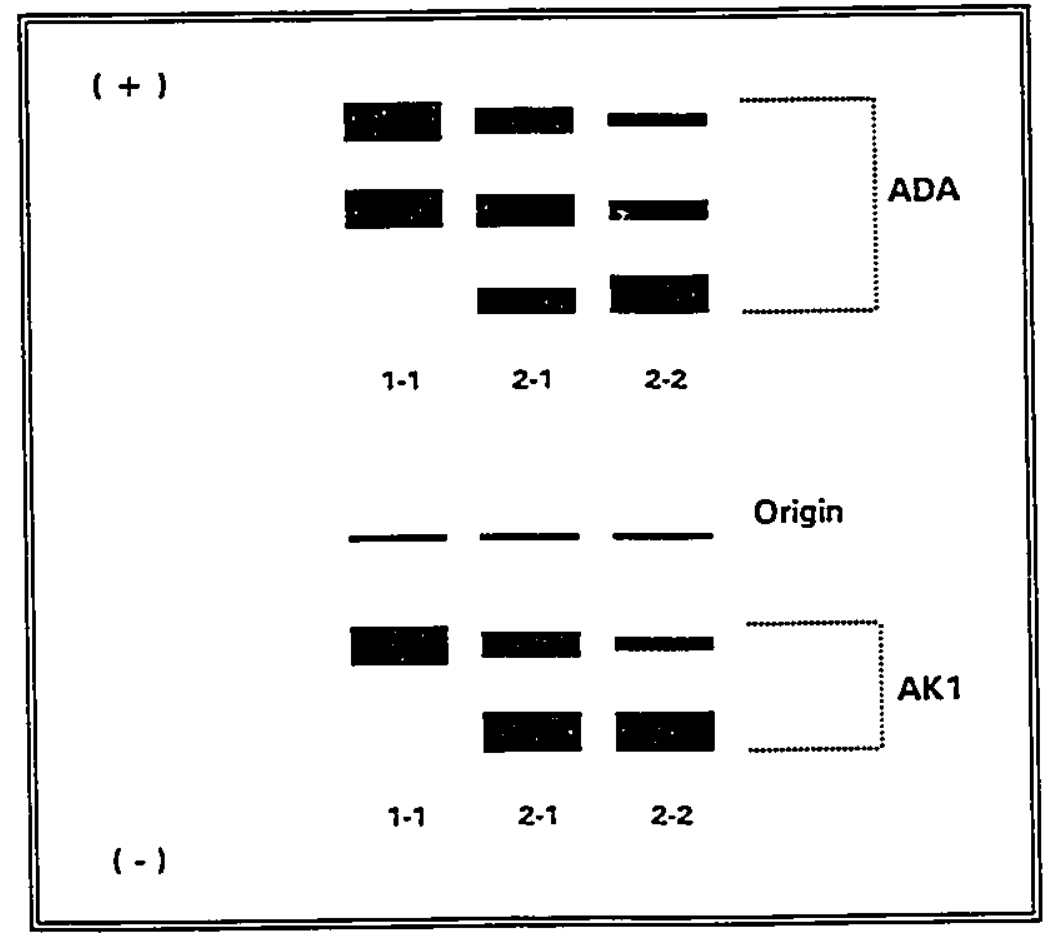

Figure 5 Diagram of the agarose gel electrophoretic banding patterns of the $\mathrm{ADA}$ and $\mathrm{AK}$, genotypes. 


\section{GC and TF Typing}

GC and TF are simultaneously determined on a $1 \%$ agarose gel (Sigma Type I) in pH 8.4 gel buffer $[0.29 \mathrm{M}$ glycine, 0.037 M trizma base]. Samples are prepared by placing a portion of the bloodstain (approximately $4 \mathrm{~mm} \times 4 \mathrm{~mm}$ ) into a microcentrifuge tube and are soaked in $6 \mathrm{M}$ urea for a minimum of thirty minutes. The samples are then extracted using chloroform to remove degraded hemoglobin. The aqueous layer is removed for analysis. Approximately $10 \mathrm{ul}$ of each sample is pipeted into gel wells $3 \mathrm{~cm}$ from the cathodic edge. The voltage is set at $400 \mathrm{~V}$ for approximately 2.5 hours at $5^{\circ} \mathrm{C}$ with a pH 8.4 tank buffer (same as gel buffer). GC and TF are developed simultaneously using an immunofixation method (Budowle and Davidson, 1984).

TF is developed using a cellulose acetate membrane $(5 \mathrm{~cm}$ $x 10 \mathrm{~cm}$ ) that is soaked with dilute $\mathrm{TF}$ antisera (Atlantic Antibodies) and placed approximately $0.5 \mathrm{~cm}$ from the origin. GC is developed using a cellulose acetate membrane $(5 \mathrm{~cm} \times 10$ cm) that is soaked with dilute GC antisera (Atlantic Antibodies) and placed approximately $5.5 \mathrm{~cm}$ from the origin. The gel is placed in a moisture chamber at room temperature and allowed to incubate for two hours.

Following incubation, the cellulose acetate membranes are removed and the gel is pressed for thirty minutes, then washed overnight in $1 \mathrm{M}$ saline to remove non-immunofixed proteins. 
The next day the gel is washed in distilled water for thirty minutes with gentle rotation. The gel is pressed for thirty minutes then dried in a $60^{\circ} \mathrm{C}$ oven for about thirty minutes. The dried gel is stained in $0.1 \%$ Coomassie Blue for about 15 minutes with rotation. The background is destained with a methanol/acetic acid/distilled water (45:10:45) solution. The gel is rinsed with distilled water, dried and typed (Figure 6).

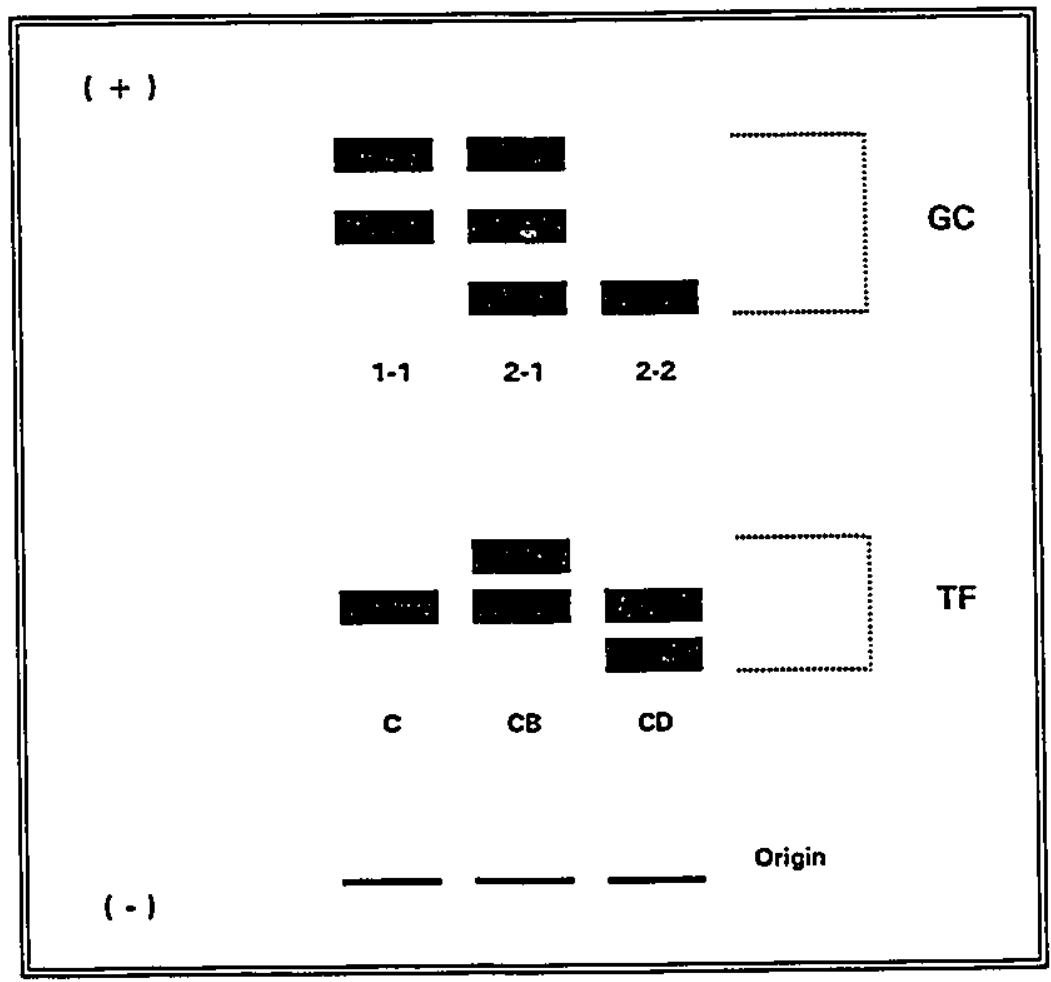
Figure 6 Diagram of agarose gel electrophoretic banding
patterns of the GC and $\mathrm{TF}$ genotypes. 


\section{HLA DQ $\alpha$ Typing}

HLA DQ $\alpha$ typing is accomplished using a PCR based typing system that is commercially available in kit form (PerkinElmer). This kit determines six of the eight alleles (1.1, $1.2,1.3,2,3,4)$ using allele specific probes (ASO). The $\mathrm{DQA} * 4$ probe sequence used in the kit detects the 4 alleles as a group only. This kit does not have the capability to subtype the 4 alleles $(4.1,4.2,4.3)$ (Cetus, 1990). However, the differences in the $D Q A * 4$ alleles can be recognized by two restriction enzymes, Fok I and Rsa I (Salazar et al., 1994). By coupling these two methods, all eight $D Q \alpha$ alleles may be determined.

DNA was extracted from dried bloodstains using an organic extraction procedure. Samples are digested in a sodium dodecyl sulfate (SDS)/proteinase $\mathrm{K}$ mixture at $56^{\circ} \mathrm{C}$ for at least one hour then extracted using phenol:chloroform: isoamyl alcohol (49.5:49.5:1) (International Biotechnologies). The aqueous layer containing the DNA is filtered and concentrated using a centricon-100 ultrafiltration device (Amicon). This procedure has been described in published reports and in Section 3.1.2 of the Amplitype Users Guide (Cetus, 1990).

The DNA recovered during the extraction procedure is evaluated for both quantity and quality. This is accomplished by examining an aliquot of the extracted DNA on a submarine electrophoresis gel [ $1 \%$ seakem LE agarose (FMC Corp) with 0.5 
ug/mL ethidium bromide in $1 X$ TBE buffer (trizma base, boric acid, EDTA at pH 8.0) \} (Sambrook, Fritsch and Maniatis, 1989). An estimate of the DNA yield is obtained by comparing the DNA band intensity of the sample extracts with quantitative DNA standards placed at the same origin.

Samples were amplified using reagents supplied in the AmpliType HLA DQ $\alpha$ Forensic DNA Amplification and Typing Kit (Perkin-Elmer) as per manufacturer's recommendations. A Perkin-Elmer 480 Thermal cycler was used with the following parameters: denature DNA at $94^{\circ} \mathrm{C}$ for 1 minute; anneal biotinylated primer with template DNA $60^{\circ} \mathrm{C}$ for 30 seconds; Taq polymerase extends primer at $72^{\circ} \mathrm{C}$ for 30 seconds; repeat denature, anneal and extension steps for 32 cycles; final primer extension link at $72^{\circ} \mathrm{C}$ for 7 minutes. Following amplification, each sample was evaluated to determine if the DNA was successfully amplified. This is accomplished by examining an aliquot of the amplified sample on a submarine electrophoresis gel [ $4 \%$ agarose gel consisting of $3 \%$ Nusieve $3: 1$ (FMC) and 1\% seakem LE agarose (FMC) with $0.5 \mathrm{ug} / \mathrm{mL}$ ethidium bromide in IX TBE buffer]. The DQ $\alpha$ product band, which will be either 239 or 242 base pairs long, should be located slightly anodic to the $246 \mathrm{bp}$ fragment of the $123 \mathrm{bp}$ DNA ladder (Life Technologies).

The DQ $\alpha$ genotype of each amplified DNA sample is determined using a reverse dot-blot procedure. Allele- 
specific probes (ASO) developed to detect six of the DQ $\alpha$ alleles $(1.1,1.2,1.3,2,3,4)$ are fixed to a nylon membrane (typing strips) and the DQo alleles are identified by hybridization with the amplified DQ $\alpha$ DNA. The biotinylated amplified DQ $\alpha$ DNA is detected on the typing strip during the color development step using a conjugate of streptavidin with horseradish peroxidase which catalyzes the oxidation of soluble colorless tetramethylbenzidine (TMB) to an insoluble blue product (Cetus, 1990). Typing strips and color development reagents are supplied in the Amplitype HLA DQC Forensic DNA Amplification and Typing kit. Typing is conducted in accordance to the manufacturer's protocol with no deviations (see Amplitype Kit package insert).

Each sample containing a DQA*4 allele is then subtyped using the endonuclease digestion method of Salazar et al. (1994). For each sample, two 20 uL aliquots of the amplified product are placed in two $0.5 \mathrm{~mL}$ microcentrifuge tubes. The restriction enzymes are prepared separately to consist of 5 units of enzyme with buffers supplied by the manufacturer (New England Biolabs) to a final volume of 5 uL. Fok I (CATCCrT) is added to one aliquot and Rsa I (GTVAC) is added to the other. Digestion for both enzymes is overnight at $37^{\circ} \mathrm{C}$. Typing is accomplished by examining an aliquot of the digested

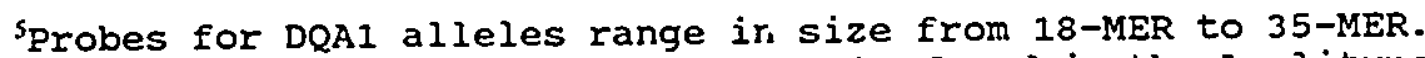
The sequences for each $5^{\prime}$ to $3^{\prime}$ probe may be found in the amplitype User Guide (Cetus 1990). 
sample on a submarine electrophoresis gel $[4 \%$ agarose gel consisting of $3 \%$ Nusieve $3: 1$ (FMC) and 1\% Seakem LE (FMC) with $0.5 \mathrm{ug} / \mathrm{mL}$ ethidium bromide in $0.5 \mathrm{X}$ TBE buffer\}. Reference samples on each gel include the 123 bp ladder (Iife Technologies) and an undigested amplified sample (242 bp fragment). The gel is visualized and photographed under ultraviolet light. DQA*4 subtypes are determined from the restriction patterns of the Fok I and Rsa I digests (Table 4).

Table 4: Restriction patterns expected with Fok $I$ and Rsa I digests of the DQAI amplified PCR product (Salazar et al., 1994)

\begin{tabular}{|c|c|c|c|c|c|}
\hline $\begin{array}{c}\text { DQA1 } \\
\text { Allele } \\
\end{array}$ & $\begin{array}{l}\text { Fok I } \\
242 \text { bE }\end{array}$ & $\begin{array}{l}\text { Fok I } \\
196 \mathrm{bp}\end{array}$ & $\begin{array}{l}\text { Fok I } \\
46 \text { bp } \\
\end{array}$ & $\begin{array}{c}\text { Rsa I } \\
223 \mathrm{bp} \\
\end{array}$ & $\begin{array}{c}\text { Rsa I } \\
196 \mathrm{bp} \\
\end{array}$ \\
\hline 1.1 & 1 & & & & 1 \\
\hline 1.2 & 1 & & & & 1 \\
\hline 1.3 & 1 & & & 1 & \\
\hline 2 & & 1 & 1 & 1 & \\
\hline 3 & 1 & & & & 1 \\
\hline 4.1 & 1 & & & & 1 \\
\hline 4.2 & & 1 & 1 & & 1 \\
\hline 4.3 & & & & & \\
\hline
\end{tabular}




\section{Quality Assurance}

$A B O$ typing of samples were performed in duplicate through forward and reverse typing. $\mathrm{PGM}_{1}$ typing of samples were performed in duplicate by establishing nominal type using the Modified Group I system and subtype by the $\mathrm{PGM}_{1}$ subtype procedure.

Each electrophoresis gel contained genetic marker standards of known types (SERI or secondary laboratory standards) to ensure that the system was operating properly and for comparison with unknown reference samples.

Genetic marker types, excluding $A B O$, were determined by the original analyst. Each electrophoretic gel, and the $D Q \alpha$ typing strips, were given to a second qualified analyst to independently determine genotypes. Any discrepancies in genotyping between the two analysts were resolved by reanalysis. Continued discrepancies were determined to be inconclusive with no genotype reported. All electrophoresis gels and the DQ $\alpha$ typing strips were photographed.

\section{Statistical Analysis}

Hardy-Weinberg expectations in a Mendelian population allow the estimation of allele and expected genotypic frequencies from the observed genotypic data. If $p$ is the frequency of allele $A$, and $q$ is the frequency of allele $B$, 
then Hardy-Weinberg equilibrium is represented by the following equation:

$$
(p+q)^{2}=p^{2}+2 p q+q^{2}=1
$$

where $p^{2}$ is the expected proportion of allele A homozygotes (AA), $q^{2}$ is the expected proportion of allele $B$ homozygotes (BB) and $2 p q$ is the expected proportion of $A B$ heterozygotes. This equation can be expanded to systems with more than two alleles by introducing additional terms (Weir, 1990; Hartl, 1988; Gaensslen, 1985).

\section{Allelic Frequency Determination}

The allele frequencies used in the Hardy-Weinberg equation are determined from the observed genotypic data, also known as the gene counting method (Gaensslen, 1985). All loci examined, except $A B O$, are codominant autosomal allele systems where both alleles are expressed in the genotype. Therefore, allelic frequencies are determined as follows:

$p=\frac{(2 \times \text { number of } p \text { homozygotes })+\text { (number of } p \text { heterozygotes })}{(2 \times \text { number of subjects observed })}$

The ABO blood group system is an autosomal allele system with some codominant relationships. If $p$ is the frequency of the $A$ allele, $q$ is the frequency of the $B$ allele, and $r$ is the frequency of the 0 allele, then the expected phenotypic frequencies are: 


$$
(p+q+I)^{2}=p^{2}+2 p r+2 p q+q^{2}+2 q r+r^{2}=1
$$

where $p^{2}$ is the expected proportion of allele A homozygotes (AA), $2 p r$ is the expected proportion of allele A heterozygotes (AO), $q^{2}$ is the expected proportion of allele B homozygotes (BB), 2qr is the expected proportion of allele B heterozygotes (BO), $2 p q$ is the expected proportion of $A B$ heterozygotes and $I^{2}$ is the expected proportion of allele 0 homozygotes. From this, the allele frequencies for each of the $A B O$ alleles are determined as follows:

$$
\begin{gathered}
p_{A}=1-\sqrt{B+O} \\
q_{B}=1-\sqrt{A+O} \\
I_{O}=\sqrt{O}
\end{gathered}
$$

where $\bar{A}, \bar{B}$ and $\bar{D}$ are the observed phenotypic frequencies of blood groups A, B and o respectively (Mourant et al., 1976).

\section{Iocus Discrimination Power}

The discrimination power $\left(P_{b}\right)$ for a locus is determined by the genotypic distribution of a population. The $P_{D}$ value indicates the probability of distinguishing between two individuals in a population. $P_{1}$ is calculated from the genotypic frequencies observed in a population using the 
equation:

$$
P_{D}=1-\Sigma x_{i}^{2}
$$

where $x_{i}$ is the frequency of each genotype (Gaensslen, 1983).

\section{single Locus Tests}

To determine if a population meets Hardy-Weinberg expectations, the observed and expected genotype counts may be compared using goodness-of-fit tests. Two methods, the traditional chi-square $\left(X^{2}\right)$ test and the log-likelihood ratio (G) are used by geneticists to determine goodness-of-fit:

$$
\begin{gathered}
X^{2}=\Sigma \frac{(\text { observed-expected })^{2}}{(\text { expected })} \\
G=2 \Sigma(\text { observed }) \ln \frac{(\text { observed })}{(\text { expected })}
\end{gathered}
$$

where there are $m(m-1) / 2$ degrees of freedom (d.f.) for a locus with $m$ alleles (Maiste, 1993). The $X^{2}$ value and the $G$ value are used with the degrees of freedom to determine the approximate p-value from published chi-square distribution charts (Weir, 1990; Hartl, 1988; Zar, 1984). A p-value is the p1-bavility that the deviation between the observed and expected values are due to chance alone. A population meets Hardy-Weinberg expectations if the probability of the deviation between the observed and expected genotypes in a genetic marker system are due to chance alone.

To determine if two populations differ significantly, a 
$X^{2}$ analysis may be performed using an $R \times C$ contingency table. The following tables (Table $5 a$ and $5 b$ ) demonstrate the procedure for obtaining the $x^{2}$ value using the $R \quad x \quad C$ contingency table:

Table 5a: TF genotypes observed in the Santa clara county vietnamese population and a vietnam population

\begin{tabular}{|c|c|c|c|}
\hline $\begin{array}{c}\text { TF } \\
\text { locus }\end{array}$ & $\begin{array}{c}\text { observed } \\
\text { Santa Clara* }\end{array}$ & $\begin{array}{c}\text { observed } \\
\text { vietnamt }\end{array}$ & total \\
\hline CC & 124 & 201 & 325 \\
\hline CD & 9 & 18 & 27 \\
\hline Total & 133 & 219 & 352 \\
\hline \multicolumn{2}{|r|}{} \\
*TF genotypes determined in this study \\
†Source: Mourant et al., 1976
\end{tabular}

"able 5b: $R \times C$ contingency table and $x^{2}$ analysis of the Santa clara county vietnamese population and a vietnam population

\begin{tabular}{|c|c|c|c|c|}
\hline $\begin{array}{c}\text { TF } \\
\text { Locus }\end{array}$ & $\begin{array}{c}\text { expected Santa } \\
\text { Clara }\end{array}$ & expected Vietnam & $\begin{array}{c}(o-e)^{2} / e \\
\text { Santa Clara }\end{array}$ & $\begin{array}{l}(0-e)^{2} / e \\
\text { Vietnam } \\
\end{array}$ \\
\hline $\mathrm{CC}$ & $\begin{array}{c}325(133 / 352) \\
=122.8\end{array}$ & $\begin{array}{c}325(219 / 352) \\
=202.2 \\
\end{array}$ & 0.0117 & 0.0071 \\
\hline $\mathrm{CD}$ & $\begin{array}{c}27(133 / 352) \\
=10.2\end{array}$ & $\begin{aligned} 27 & (219 / 352) \\
& =16.8\end{aligned}$ & 0.1412 & 0.0857 \\
\hline & & & $x^{2}=0.1529$ & $x^{2}=0.0928$ \\
\hline
\end{tabular}

with degrees of freedom $(d . f)=.(r-1)(c-1)$ where $r$ is the the number of rows and $c$ is the number of columns (Sokal and Rohlf, 1981; Race and Sanger, 1976). The $X^{2}$ value is ther. 
used with the degrees of freedom to determine the approximate p-value from published chi-square distribution charts (Weir, 1990; Hartl, 1988).

Two Iocus Tests

Tests for two locus associations are performed by comparing observed genotypes to expected genotypes using goodness-of-fit tests or an exact test method. Exact tests, conditional on observed allelic frequencies, consider all possible arrays of genotypes for the given alleles (Weir, 1990). Exact tests are preferred over a goodness-of-fit tests when the sample genotype frequencies will be zero or very small (Guo and Thompson, 1992). P-values are calculated by computer using a method that shuffles the alleles at each locus and then computes the probability of the genotypic array conditional on the allelic array based on programs described by Guo and Thompson (1992). The values determined are based on 10,000 shuffles so that the results are expected (with $95 \%$ confidence) to be accurate to 2 decimal places (Weir, 1994b).

\section{Significance of the p-value}

A p-value indicates the probability that the deviation between the observed and expected values are due to chance alone. A p-value of 0.05 or lower is considered a significant deviation which casts doubt on the interpretation of the data 
set. P-values greater than 0.05 are considered nonsignificant deviations with no reason to reject an interpretation of the data set (Weir, 1990; Crow, 1986; Rothwell, 1979). The tests performed in this study reject a data set when $p \leq 0.05$. 


\section{Results}

Samples collected from the Santa clara County Vietnamese population were typed in each of the following genetic marker systems, $D Q \alpha, P G M_{1}, A C P_{1}, A B O, A D A, A K_{1}, E S D, G C, P e p A$, and $T E$. of the 135 samples tested, genetic marker profiles consisting of the eight polymorphic loci $\left(D Q \alpha, P G M_{1}, A C P_{1}, A B O, A D A, E S D\right.$, GC, TF) were determined for only 130 of the samples. The degradation of protein markers in postmortem blood samples (Table 6) accounts for the reduction in the sample population.

Table 6: Number of samples with typing results $(n=135)$

\begin{tabular}{||c|c|}
\hline Locus & Number of samples \\
\hline DQQ & 135 \\
\hline PGM $_{1}$ & 135 \\
\hline ACP 1 & 135 \\
\hline ABO & 135 \\
\hline TF & 133 \\
\hline ADA & 133 \\
\hline AK & 135 \\
\hline ESD & 133 \\
\hline GC & 133 \\
\hline PePA & 123 \\
\hline
\end{tabular}




\section{Allelic Frequencies}

The observed genotypes (Tables $7 \mathrm{a}, 7 \mathrm{~b}, 7 \mathrm{c}$ ) yield allelic frequencies (Table 8) for each loci in the population using the gene counting method. To minimize the effects of very rare alleles on tests for association, rare alleles were counted as the most common allele for that particular system (Weir, 1994b). The three rare alleles affected are as follows: $\mathrm{PGM}_{1}$ type 1+/variant was counted as a $1+1+; \mathrm{ACP}_{1}$ type CA was counted as a BA; GC type 1-Y was counted as a $1-1$. The allele frequencies for the rare variants are 0.004 for $\mathrm{PGM}_{1}$ variant, 0.004 for $A C P_{1} C$ and 0.004 for $G C Y$. 
Table 7a: DQAI locus genotypes observed in the Santa Clara county vietnamese population $(n=130)$

\begin{tabular}{|c|c|}
\hline Genotype & Observed \\
\hline $1.1,1.1$ & 5 \\
\hline $1.1,1.2$ & 6 \\
\hline $1.1,1.3$ & 1 \\
\hline $1.1,2$ & 2 \\
\hline $1.1,3$ & 11 \\
\hline $1.1,4.1$ & 10 \\
\hline $1.1,4.3$ & 17 \\
\hline $1.2,1.2$ & 2 \\
\hline $1.2,1.3$ & 1 \\
\hline $1.2,2$ & 1 \\
\hline $1.2,3$ & 9 \\
\hline $1.2,4.1$ & 3 \\
\hline $1.2,4.3$ & 6 \\
\hline $1.3,3$ & 4 \\
\hline $1.3,4.1$ & 1 \\
\hline $1.3,4.3$ & 5 \\
\hline 2,2 & 1 \\
\hline 2,3 & 1 \\
\hline 2.4 .1 & 1 \\
\hline $2,4.3$ & 3 \\
\hline 3,3 & 5 \\
\hline $3,4.1$ & 9 \\
\hline $3,4.3$ & 8 \\
\hline $4.1,4.1$ & 1 \\
\hline $4.1,4.3$ & 7 \\
\hline $4.3,4.3$ & 10 \\
\hline
\end{tabular}


Table 7b: PGK, locus genotypes observed in the Santa clara County Vietnamese population $(n=130)$

\begin{tabular}{|c|c|}
\hline Gezotype & Observed \\
\hline $1+1+$ & 46 \\
\hline $1+1-$ & 23 \\
\hline $1+2+$ & 19 \\
\hline $1+2-$ & 18 \\
\hline $1-1-$ & 2 \\
\hline $1-2+$ & 4 \\
\hline $1-2-$ & 5 \\
\hline $2+2+$ & 6 \\
\hline $2+2-$ & 5 \\
\hline $2-2-$ & 1 \\
\hline $1+$ variant & 1 \\
\hline
\end{tabular}


Table 7C: $A C P_{1}, A B O, T F, A D A, E S D$ and $G C$ genotypes observed in the Santa clara county vietnamese population (n=130)

\begin{tabular}{|c|c|c|}
\hline Iocus & Genotype & Observed \\
\hline \multirow[t]{4}{*}{$\mathrm{ACP}_{1}$} & $A A$ & 7 \\
\hline & BB & 65 \\
\hline & $\mathrm{BA}$ & 57 \\
\hline & $C A$ & 1 \\
\hline \multirow[t]{4}{*}{ ABO } & A & 26 \\
\hline & B & 44 \\
\hline & $A B$ & 13 \\
\hline & 0 & 47 \\
\hline \multirow[t]{2}{*}{$T F$} & $\mathrm{CC}$ & 121 \\
\hline & $C D$ & 9 \\
\hline \multirow[t]{2}{*}{$A D A$} & $1-1$ & 113 \\
\hline & $2-1$ & 17 \\
\hline \multirow[t]{3}{*}{ ESD } & $1-1$ & 53 \\
\hline & $2-1$ & 60 \\
\hline & $2-2$ & 17 \\
\hline \multirow[t]{4}{*}{ GC } & $1-1$ & 78 \\
\hline & $1-Y$ & 1 \\
\hline & $2-1$ & 48 \\
\hline & $2-2$ & 3 \\
\hline
\end{tabular}


Table 8: Allelic frequency distributions for the Santa clara county vietnamese population $(n=130)$

\begin{tabular}{|c|c|c|}
\hline Locus & Allele & Frequency \\
\hline$D Q \alpha$ & $\begin{array}{c}1.1 \\
1.2 \\
1.3 \\
2 \\
3 \\
4.1 \\
4.2 \\
\end{array}$ & $\begin{array}{l}0.219 \\
0.115 \\
0.046 \\
0.039 \\
0.200 \\
0.127 \\
0.254 \\
\end{array}$ \\
\hline $\mathrm{PGM}_{1}$ & $\begin{array}{l}1- \\
1+ \\
2- \\
2+\end{array}$ & $\begin{array}{l}0.139 \\
0.592 \\
0.115 \\
0.154\end{array}$ \\
\hline$A C P_{1}$ & $\begin{array}{l}\text { A } \\
\text { B }\end{array}$ & $\begin{array}{l}0.277 \\
0.723\end{array}$ \\
\hline ABO & $\begin{array}{l}\text { A } \\
\text { B } \\
\text { O }\end{array}$ & $\begin{array}{l}0.163 \\
0.250 \\
0.602 \\
\end{array}$ \\
\hline$T F$ & $\begin{array}{l}\text { C } \\
\text { D }\end{array}$ & $\begin{array}{l}0.965 \\
0.035\end{array}$ \\
\hline ADA & $\begin{array}{l}1 \\
2\end{array}$ & $\begin{array}{l}0.935 \\
0.065\end{array}$ \\
\hline $\mathrm{AK}_{1}$ & 1 & 1.000 \\
\hline ESD & $\begin{array}{l}1 \\
2 \\
\end{array}$ & $\begin{array}{l}0.638 \\
0.362 \\
\end{array}$ \\
\hline GC & $\begin{array}{l}1 \\
2\end{array}$ & $\begin{array}{l}0.792 \\
0.208 \\
\end{array}$ \\
\hline PepA & 1 & 1.000 \\
\hline
\end{tabular}

a) allelic frequencies were determined using the gene counting method

b) $n=$ number of samples 


\section{Ioci Discrimination Power}

The discrimination power for each locus tested in the Santa clara County vietnamese population is shown in Table 9. $A K_{1}\left(P_{D}=0\right)$ and PepA $\left(P_{D}=0\right)$ are essentially monomorphic in the vietnamese population while $A D A\left(P_{D}=0.23\right)$ and $T F\left(P_{D}=0.13\right)$ have low discrimination potential. Therefore, these loci have limited value for identity testing in the vietnamese population. The other loci tested demonstrate varying degrees of discrimination potential in the Vietnamese population. As expected, the $D Q \alpha$ locus with 7 alleles has the highest discrimination potential followed by the 4 allele PGM $_{1}$ system.

Table 9: Loci discrimination power $\left(P_{p}\right)$ for the Santa clara county vietnamese population

\begin{tabular}{|c|c|c|}
\hline Locus & $\begin{array}{c}\text { Alleles } \\
\text { Observed }\end{array}$ & $P_{D}$ \\
\hline$D Q \alpha$ & 7 & 0.94 \\
\hline PGM $_{\mathrm{f}}$ & 4 & 0.80 \\
\hline$A C P_{1}$ & 2 & 0.56 \\
\hline$A B O$ & 3 & 0.71 \\
\hline$T F$ & 2 & 0.13 \\
\hline$A D A$ & 2 & 0.23 \\
\hline$A K_{1}$ & 1 & 0.00 \\
\hline$E S D$ & 2 & 0.60 \\
\hline$G C$ & 2 & 0.50 \\
\hline PepA & 1 & 0.00 \\
\hline
\end{tabular}

a) $P_{0}=1-\Sigma x_{i}^{2} ;$ where $x_{i}$ is the frequency of each genotype 
Allelic Frequency Comparison of Various Popuiations The genotypic data available for native vietnamese populations are shown in Table 10. This data was obtained from published surveys and represents populations tested in vietnam. The $p$-values obtained from an $R \times c$ contingency table $x^{2}$ analysis showed no significant deviations between the observed genotypic frequencies in the Santa clara County Vietnamese population and the native country vietnamese population for the $A C P_{1}, A B O, A K_{1}, G C$ and $T F$ loci.

The allelic frequency distributions of the major population groups in santa clara county [Vietnamese, Caucasian, Black and Mexican-American (Hispanic)] are shown in Figures $7 a, 7 b$ and Table 11 for eight polymorphic loci (DQ $\alpha$, $\left.\mathrm{PGM}_{1}, A C P_{1}, A B O, A D A, E S D, G C, T F\right)$. Differences are noted in varying degrees between the vietnamese, Caucasian, Black and Mexican-American (Hisparic) populations. 
Table 10: observed genotypes in the Santa clara county vietnamese and vietnam populations

\begin{tabular}{|c|c|c|c|c|}
\hline Locus & $\begin{array}{c}\text { Genotype } \\
\text { or } \\
\text { Phenotype }\end{array}$ & $\begin{array}{c}\text { Observed } \\
\text { Genotype } \\
\text { or } \\
\text { Phenotype } \\
\text { (Santa clara) } \\
\end{array}$ & $\begin{array}{c}\text { Observed } \\
\text { Genotype } \\
\text { or } \\
\text { Phenotype } \\
\text { (Vietnam)* } \\
\end{array}$ & $\begin{array}{c}\text { p value } \\
\text { (p<0.05 is } \\
\text { significant) }\end{array}$ \\
\hline $\mathrm{ACP}_{3}$ & $\begin{array}{l}A A \\
B B \\
C C \\
B A \\
C A \\
C B\end{array}$ & $\begin{array}{c}8 \\
67 \\
0 \\
59 \\
1 \\
0 \\
(n=135) \\
\end{array}$ & $\begin{array}{c}5 \\
36 \\
0 \\
24 \\
0 \\
0 \\
(n=65) \\
\end{array}$ & $0.50<p<0.70$ \\
\hline ABO & $\begin{array}{c}A \\
B \\
A B \\
0\end{array}$ & $\begin{array}{c}28 \\
47 \\
13 \\
47 \\
(n=135) \\
\end{array}$ & $\begin{array}{c}24809 \\
34825 \\
6734 \\
47654 \\
(n=114022) \\
\end{array}$ & $0.10<p<0.20$ \\
\hline$A X_{1}$ & $\begin{array}{l}1-1 \\
2-1 \\
2-2\end{array}$ & $\begin{array}{c}134 \\
0 \\
0 \\
(n=134) \\
\end{array}$ & $\begin{array}{c}149 \\
1 \\
0 \\
(n=150) \\
\end{array}$ & $0.30<p<0.50$ \\
\hline GC & $\begin{array}{l}1-1 \\
2-1 \\
2-2\end{array}$ & $\begin{array}{c}80 \\
49 \\
3 \\
(n=132) \\
\end{array}$ & $\begin{array}{c}88 \\
42 \\
6 \\
(n=136) \\
\end{array}$ & $0.30<p<0.50$ \\
\hline TF & $\begin{array}{l}\mathrm{CC} \\
\mathrm{CD} \\
\mathrm{CB}\end{array}$ & $\begin{array}{c}124 \\
9 \\
0 \\
(n=133) \\
\end{array}$ & $\begin{array}{c}201 \\
18 \\
0 \\
(n=219) \\
\end{array}$ & $0.50<p<0.70$ \\
\hline
\end{tabular}

a) p-values were determined using $R \times C$ contingency test;

a-values are significant if $p \leq 0.05$

b) $\mathrm{n}=$ number of samples 


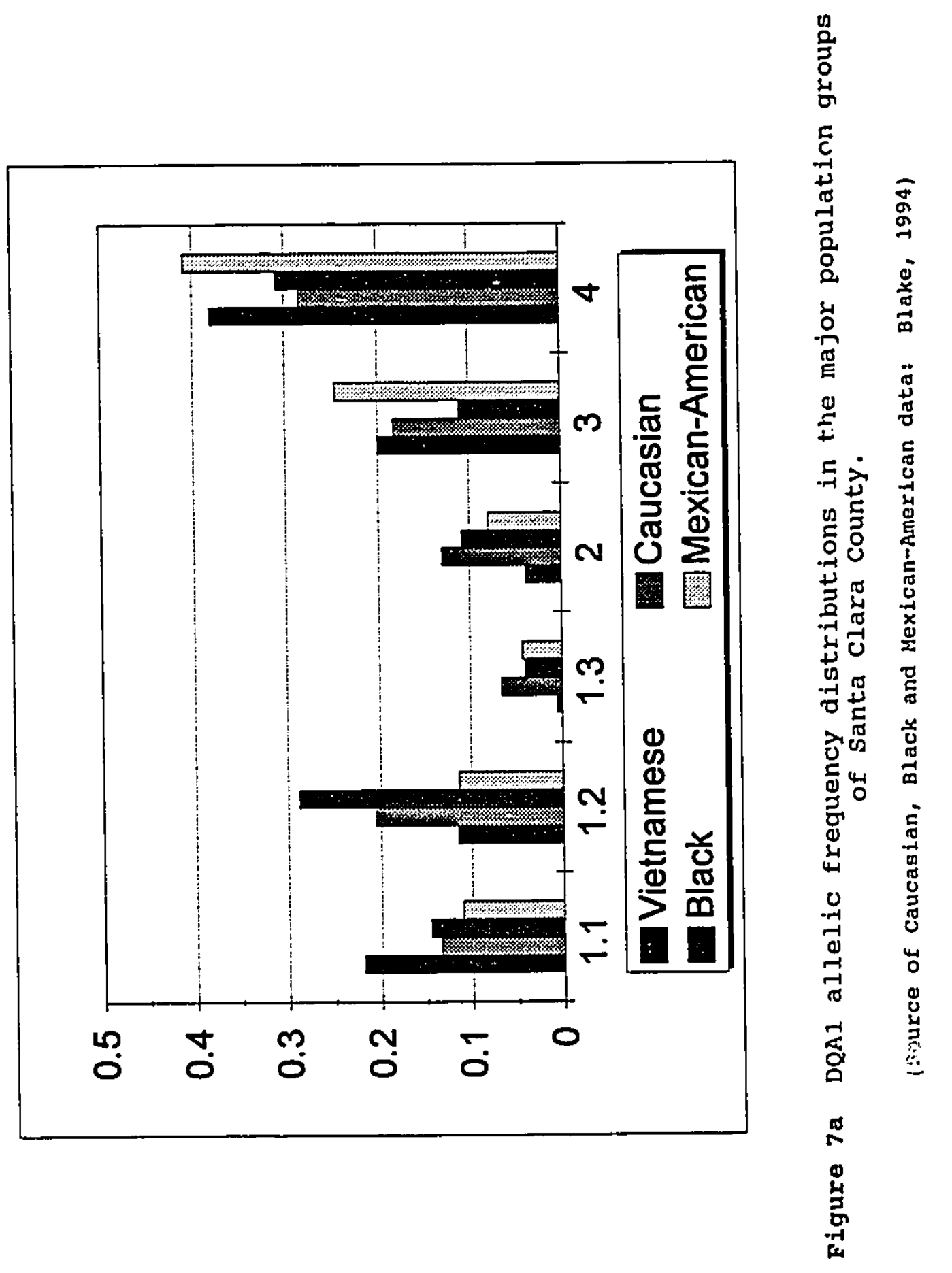



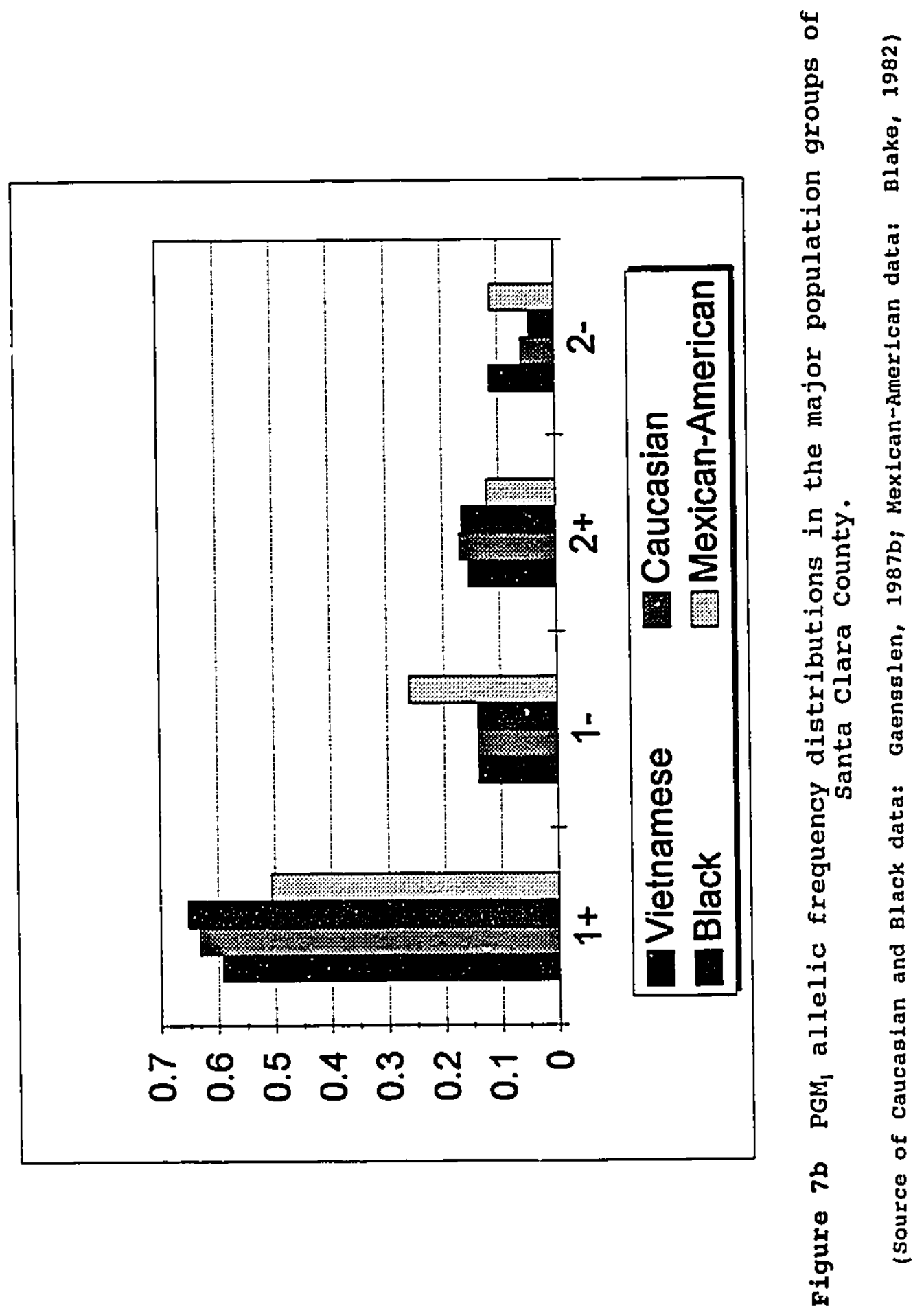
Table 11: Allele and phenotypic frequency distribution in the major population groups of santa clara county

\begin{tabular}{|c|c|c|c|c|c|}
\hline Iocus & $\begin{array}{c}\text { Allele } \\
\text { Frequencies }\end{array}$ & $\begin{array}{c}\text { Santa } \\
\text { Clara co } \\
\text { Vietnamese }\end{array}$ & Caucasiant & Blackt & Hispanict \\
\hline$A C P_{1}$ & $\begin{array}{l}\mathrm{A} \\
\mathrm{B} \\
\mathrm{C}\end{array}$ & $\begin{array}{l}0.277 \\
0.723 \\
0.004 \\
\end{array}$ & $\begin{array}{l}0.319 \\
0.638 \\
0.043 \\
\end{array}$ & $\begin{array}{l}0.222 \\
0.769 \\
0.010 \\
\end{array}$ & $\begin{array}{l}0.244 \\
0.736 \\
0.020 \\
\end{array}$ \\
\hline $\mathrm{ABO}$ * & $\begin{array}{c}A \\
B \\
A B \\
O \\
\end{array}$ & $\begin{array}{l}0.200 \\
0.338 \\
0.100 \\
0.362 \\
\end{array}$ & $\begin{array}{l}0.412 \\
0.103 \\
0.038 \\
0.447 \\
\end{array}$ & $\begin{array}{l}0.263 \\
0.203 \\
0.041 \\
0.493 \\
\end{array}$ & $\begin{array}{l}0.285 \\
0.100 \\
0.023 \\
0.593 \\
\end{array}$ \\
\hline$T F$ & $\begin{array}{l}\text { C } \\
\text { D } \\
\text { B } \\
\end{array}$ & $\begin{array}{l}0.965 \\
0.035 \\
0.000 \\
\end{array}$ & $\begin{array}{l}0.995 \\
0.002 \\
0.003 \\
\end{array}$ & $\begin{array}{l}0.974 \\
0.026 \\
0.000 \\
\end{array}$ & $\begin{array}{l}1.000 \\
0.000 \\
0.000\end{array}$ \\
\hline $\mathrm{ADA}$ & $\begin{array}{l}1 \\
2 \\
\end{array}$ & $\begin{array}{l}0.935 \\
0.065 \\
\end{array}$ & $\begin{array}{l}0.949 \\
0.051 \\
\end{array}$ & $\begin{array}{l}0.988 \\
0.012 \\
\end{array}$ & $\begin{array}{l}0.977 \\
0.023 \\
\end{array}$ \\
\hline ESD & $\begin{array}{l}1 \\
2 \\
\end{array}$ & $\begin{array}{l}0.638 \\
0.362 \\
\end{array}$ & $\begin{array}{l}0.890 \\
0.110 \\
\end{array}$ & $\begin{array}{l}0.912 \\
0.088 \\
\end{array}$ & $\begin{array}{l}0.853 \\
0.147 \\
\end{array}$ \\
\hline GC & $\begin{array}{l}1 \\
2 \\
\end{array}$ & $\begin{array}{l}0.792 \\
0.208 \\
\end{array}$ & $\begin{array}{l}0.718 \\
0.282 \\
\end{array}$ & $\begin{array}{l}0.884 \\
0.116 \\
\end{array}$ & $\begin{array}{l}0.785 \\
0.215 \\
\end{array}$ \\
\hline
\end{tabular}

fSource: Gaensslen et al., I987a (ABO); 19870 (ACP,, ADA, ESD); $1987 \mathrm{C}(\mathrm{GC}, \mathrm{TF})$

*phenotypic frequencies reported

\section{Single Locus Tests}

Two goodness-of-fit tests, the chi-square $\left(X^{2}\right)$ and the log-likelihood ratio tests were performed to test for HardyWeinberg equilibrium at each of the eight polymorphic loci. The expected values were calculated from allele frequency data (Table 8) using the Hardy-Weinberg equation where a homozygote is the allele frequency squared $\left(p^{2}\right)$ and a heterozygote is twice the product of the two alleles (2pq). This calculation assumes that the distribution of genotypes in the population are in Hardy-Weinberg equilibrium. This assumption was tested 
by comparing the observed values to the expected values and determining the $X^{2}$ and $G$ values (Table 12). The two goodnessof-fit tests, chi-square and log-likelihood ratio, show no evidence of departure from Hardy-Weinberg equilibrium for the eight polymorphic loci. These findings were confirmed by an exact test (Zaykin et al., 1995; Weir, 1994b; Guo and Thompson, 1992) for all loci except ABO.

Table 12: Hardy-Weinberg Test Results

\begin{tabular}{|c|c|c|c|c|}
\hline Iocus & $x^{2}$ & $\boldsymbol{G}$ & d.f. & $\begin{array}{c}\text { Exact Test } \\
\text { p-value* }\end{array}$ \\
\hline$D Q \alpha$ & 16.25 & 15.55 & 21 & 0.79 \\
\hline$P G M_{1}$ & 4.92 & 4.48 & 6 & 0.58 \\
\hline $\mathrm{ACP}_{1}$ & 1.69 & 1.77 & 1 & 0.26 \\
\hline$A B O$ & 1.07 & -6.81 & 3 & $n t$ \\
\hline$T F$ & 0.16 & 0.32 & 1 & 1.00 \\
\hline$A D A$ & 0.64 & 1.19 & 1 & 1.00 \\
\hline ESD & 0.00 & 0.00 & 1 & 1.00 \\
\hline GC & 1.93 & 2.16 & 1 & 0.28 \\
\hline
\end{tabular}

*Source: Weir, 1994b

Hardy-Weinberg calculations for each locus:

a) observed values are from the empirical data

b) expected values are calculated using the Hardy-Weinberg

c) $\quad X^{2}=\Sigma(0-e)^{2} / e$ and $G=2 \Sigma(0) \ln (0 / e)$ where 0 is the observed count and $e$ is the expected count

d) degrees of freedom $(d . f)=.m(m-1) / 2$, where $m$ is the number of alleles

e) $x^{2}$ and $G$ values with the degrees of freedom (d.f.) are used to determine approximate p-values from published chi-square distribution tables

Exact test p-values were determined by 10,000 shuffles of alleles. A $p$-value is significant if $\mathrm{p} \leq 0.05$. 
Two Locus Tests

Except for $\mathrm{ABO}$ and $\mathrm{AK}_{1}$, which are both on chromosome 9, all loci studied are on different chromosomes (Table 2) and are expected to be in gametic, or linkage equilibrium with respect to each other. Tests to determine any detectable associations between loci (DQ $\left.\alpha, \mathrm{PGM}_{1}, \mathrm{ACP}_{1}, \mathrm{ADA}, \mathrm{ESD}, \mathrm{GC}, \mathrm{TF}\right)$ were conducted to confirm this assumption. There are many different approaches to characterize associations between frequencies at two loci. For loci other than $A B O$, a useful way is to compare the observed two-locus genotypic frequencies to the expected two-locus genotypic frequencies using a chisquare goodness-of-fit test, assuming independence of alleles both within and between loci (Maiste, 1993). The expected two-locus genotypic frequencies are simply the products of the corresponding allele frequencies (Weir, 1994b). If two loci have $m, n$ alleles, this chi-square statistic has $[m(m+1) n(n+1) / 4]-m-n+1$ degrees of freedom. The results are shown in Table 13. Tests were not performed on pairs involving $\mathrm{AK}_{1}$ or $\mathrm{PepA}$, since those loci have only one allele in the database. The two-locus chi-square tests were confirmed by an exact test and the p-values are shown in Table 13. Two-locus associations are established if the p-value $\leq$ 0.05 . For all twenty-one pairs of loci, there was no evidence of an association between the allelic frequencies, within or between loci. 
A linkage relationship might exist between the $A B O$ and $\mathrm{AK}_{\mathrm{I}}$ loci due to their proximity to each other on chromosome 9. Since $A K_{1}$ is monomorphic in the santa clara county vietnamese population, tests for associations could not be performed. However, Hernandez et al. (1990) indicate no evidence of association between these two loci. 
Table 13: Tests for association at pairs of loci $(n=130)$ *

\begin{tabular}{|c|c|c|c|}
\hline Ioci & Chi-square & d.f. & $\begin{array}{c}\text { Exact Test } \\
\text { p-value }\end{array}$ \\
\hline $\mathrm{DQ} \alpha_{1} \mathrm{PGM}_{1}$ & 204.23 & 270 & 0.90 \\
\hline$D Q \alpha, A C P_{1}$ & 56.92 & 70 & 0.93 \\
\hline $\mathrm{DQ} \alpha, \mathrm{ADA}$ & 37.62 & 76 & 0.92 \\
\hline DQC, ESD & 75.85 & 76 & 0.54 \\
\hline $\mathrm{DQ \alpha}, \mathrm{GC}$ & 76.86 & 76 & 0.75 \\
\hline $\mathrm{DQQ}, \mathrm{TF}$ & 40.70 & 76 & 0.80 \\
\hline$P G M_{1}, A C P_{1}$ & 19.66 & 25 & 0.82 \\
\hline$P G M_{1}, A D A$ & 10.40 & 25 & 0.93 \\
\hline$P G M_{1}, E S D$ & 23.18 & 25 & 0.46 \\
\hline $\mathrm{PGM}_{1}, \mathrm{GC}$ & 22.02 & 25 & 0.51 \\
\hline $\mathrm{PGM}_{1}, \mathrm{TF}$ & 10.23 & 25 & 0.71 \\
\hline$A C P, A D A$ & 3.06 & 6 & 0.72 \\
\hline$A C P_{1}, E S D$ & 3.95 & 6 & 0.77 \\
\hline$A C P_{1}, G C$ & 7.45 & 6 & 0.39 \\
\hline$A C P_{1}, T F$ & 2.31 & 6 & 0.74 \\
\hline ADA, ESD & 1.02 & 6 & 0.97 \\
\hline ADA, GC & 2.92 & 6 & 0.84 \\
\hline ADA, TF & 1.59 & 6 & 0.67 \\
\hline ESD, GC & 3.11 & 6 & 0.90 \\
\hline ESD, TF & 0.52 & 6 & 0.94 \\
\hline GC, TF & 3.33 & 6 & 0.57 \\
\hline
\end{tabular}

Hardy-Weinberg calculations for each pair of loci:

a) observed values are from the empirical data

b) expected values are calculated using the Hardy-Weinberg equation

c) $x^{2}=\Sigma(0-e)^{2} / e$ where 0 is the observed count and $e$ is the expected count

d) d.f. $=[m(m+1) n(n+1) / 4]-m-n+1$

e) $x^{2}$ values with degrees of freedom (d.f.) are used to determine approximate p-values from published chi-square distribution tables

Exact test p-values were determined by 10,000 shuffles of alleles. A p-value is significant if $\mathrm{p} \leq 0.05$. 


\section{Conclusions}

Statistical interpretation of genetic marker profiles determined in human identity testing require allelic frequency distribution data for the relevant populations. In a forensic setting, the relevant populations are determined by the geographical area where the crime occurred. In Santa clara county, the growing vietnamese community reprasents a significant portion of a general population that includes Caucasians, Mexican-Americans (Hispanic) and Blacks. Extensive population surveys are available for these population groups (Blake, 1994; Gaensslen et al., 1987a, 1987b, 1987c; Grunbaum et al., 1980), while no such data is available for Vietnamese-Americans. This study establishes genotypic and allelic frequency distributions for ten genetic markers in the santa clara county vietnamese population (Tables 7a-c, Table 8).

of the ten genetic markers tested in the santa clara County vietnamese population, eight are polymorphic in the popliation. The distribution of the genotype frequencies for these eight polymorphic loci $\left(D Q \alpha, P G M_{1}, A C P_{1}, A B O, T F, A D A\right.$, ESD, GC) meet Hardy-Weinberg expectations (Table 12). In addition, no significant deviations were found when five loci $\left(A C P_{1}, A B O, A K_{1}, G C, T F\right)$ were compared to the published data (Table 10). By examining the empirical data in this manner, 
discrepancies in gene frequencies may be identified. Deviate results would be indicative of nonrandom sampling, insufficient sample size or typing errors (Gaensslen, 1985; Dykes, 1982).

Zoci Discrisination Power

A necessary feature of a genetic marker for identity testing is the ability of the polymorphic marker to differentiate between individuals in a population. The discrimination power, $P_{D}$, is a probability term that describes the discrimination potential of a genetic marker in a specific population. A high $P_{D}$ value indicates a higher probability of being able to distinguish between two individuals randomly chosen from the population (Gaensslen, 1983). Of the loci tested in the Santa Clara County Vietnamese population (Table 9), the $D Q \alpha$ locus is the most discriminating and useful for identity testing. $\mathrm{AK}_{1}$ and $\mathrm{PepA}$ behave as monomorphic markers in this population and should not be used for identity testing. When the eight polymorphic loci are combined in a genetic profile $\left(D Q \alpha, \mathrm{PGM}_{1}, \mathrm{ACP}_{1}, \mathrm{ABO}, \mathrm{ADA}, \mathrm{ESD}, \mathrm{GC}, \mathrm{TF}\right)$, the discrimination power for the Santa clara county Vietnamese population is significantly increased $\left(P_{\mathrm{D}}>99 \%\right)$. This illustrates the need for a conetic profile to consist of a number of polymorphic loci. 
Santa clara county Vietnamese population Compared to Vietnam Populations

The influx of Vietnamese individuals into the United States is a recent occurrance. The end of the United States involvement. in the Vietnam war and the start of major resettlement efforts began in 1975 under the Indo-China Migration and Refugee Assistance Act. Approximately $96 \%$ of the estimated 614,547 Vietnamese individuals in the United states have arrived since 1975. This represents the single largest refugee group ever to arrive in the United states in so short a time (Bureau of the Census, 1993). This short time span has allowed comparatively little intermixing with the host country and, as a result, the genetic make up of recent emigres chould reflect that of their native country. Indeed, a comparison of the Santa clara county vietnamese population with published surveys of Vietnam populations (Mourant et al., 1976) show no significant difference in five genetic marker systems (Table 10).

Comparison of the Major Population Groups in Santa Clara county

Allelic or phenotypic frequency differences have been documented for many genetic markers in various populations (Blake, 1994; Budowle et al., 1994; Gaensslen et al., 1987a, 
1987b, 1987c; Grunbaum, 1980). However, these differences have not been established for the vietnamese population. Without population frequency data that is appropriate for a specific region, the probability that a genetic marker profile could have come from a given source may be too conservative (underestimate) or exaggerated (overestimate) when using inappropriate popula'ion data.

The allelic or phenotypic frequencies established for the vietnamese population were compared to population groups that reflect the santa clara county population to determine if differences exist (Blake: 1994; Gaensslen et al., 1987a, 1987b, 1987c; Grunbaum, 1980). Allelic and phenotypic frequency differences were noted between the vietnamese, Caucasian, Mexican-American (Hispanic) and Black populations when comparing eight genetic markers $\left(D Q \alpha, P G M_{1}, A C P_{1}, A B O, T F\right.$, ADA, ESD, GC) (Figures 7a, 7b, Table 11). These findings reiterate the necessity for reporting match probability statistics for the relevant population groups in a given area.

\section{Independence Testing}

The significance of an identification is based on the statistical interpretation of a genetic marker profile. A frequency estimate of the combination of types is simply the product $c i$ the single locus frequencies in the profile, provided ine loci are inherited independently. Therefore, 
independence of the genetic markers used in identity testing must be established for probability calculations. Independence of a number of polymorphic protein markers has been empirically established in major populations groups such as Caucasian, Black and Hispanic (Hernandez et al., 1990; Grunbaum et al., 1980; Gaensslen, 1983) while little information is available regarding the linkage relationship (independence) of the DQQ locus with protein markers (Budowle et al., 1994; Weir, 1994a).

In this study, no associations were observed between six protein markers $\left(\mathrm{PGM}_{1}, A C P_{1}, A D A, E S D, G C, T F\right)$ and the $D Q \alpha$ locus (Table 13). These results are consistent with recent studies and are expected due to chromosome location (Table 2). No associations were observed in oakland Blacks between four protein markers $\left(P_{G M}, P e p A, C A 2, A B O\right)$ and the $D Q \alpha$ locus (Weir, 1994a), while no associates were observed between the DQQ locus and GC locus in Caucasian, Black and Hispanic populations (Budowle et al., 1994).

In conclusion, the distribution of the genotype frequencies for ten genetic markers $\left(\mathrm{D} ; \alpha, \mathrm{PGM}_{1}, \mathrm{ACP}, \mathrm{ABO}, \mathrm{TF}\right.$, $\left.A D A, A K_{1}, E S D, G C, P e p A\right)$ were determined in the santa clara County vietnamese proulation. of the ten markers studied, eight $\left(D Q \alpha, P G M_{1}, A C P_{1}, A B O, T F, A D A, E S D, G C\right)$ were determin sd to be polymorphic and met Hardy-Weinberg expectations.

The strength of genetic marker typing as a tool for human 
identification is based on the multiplication of single locus genotype frequencies in a genetic profile. The combined product of single locus frequencies can significantly increase the ability to discriminate between individuals in a given population.

The use of blood group and protein marker systems for individual identification is well characterized and established in laboratories engaged in identity testing. However, the disadvantages of these markers is the relatively rapid degradation of proteins in physiological fluid stains and postmortem samples.

The application of PCR based DNA testing methods for individual identification is a recent occurrence in identity testing laboratories. These systems are not as well characterized or established as the blood group and protein marker systems. In addition, the assumption of independence has not been empirically verified as with the blood group and protein genetic marker systems. However, the major advantage of the PCR based DNA typing systems is the ability to type even the most degraded DNA sample.

Based on the strengths and weaknesses of protein and DNA genetic markers, a combination of protein genetic markers and DNA polymorphisms would complement each other and increase the discrimination power for individual identification. However, independence of the PCR based DNA typing systems must be 
established for their inclusion in a genetic profile. In this study, no associations were noted between the HLA DQQ Iocus and six protein markers $\left(\mathrm{PGM}_{1}, \mathrm{ACP}_{1}, \mathrm{ADA}, \mathrm{ESD}, \mathrm{GC}, \mathrm{TF}\right)$. The independence of these Ioci validate the use of the product rule when estimating genetic profile match probability for individual identification. 


\section{References}

Ad Hoc Committee on Individual Identification by DNA Analysis, The American Society of Human Genetics (1990) Individual Identification by DNA Analysis: Points to Consider. American Journal of Human Genetics, 46:631-634.

Asian \& Pacific Islander Center for Census Information and Services (ACCIS) (1992) Our Ten Years of Growth: A Demographic Analysis on Asian and Pacific Islander Americans. Asian/Pacific Islander Data Consortium, San Francisco, CA.

Begovich, A.B., Mcclure, G.R., Suraj, V.C., Helmuth, R.C., Fildes, N., Bugawan, T.I., Erlich, H.A. and W. Klitz (1992) Polymorphism, Recombination, and Linkage Disequilibrium within the HLA Class II Region. Journal of Immunology, 148(1):249258 .

Blake, E.T. (1982) PGM Subtyping Data for California Blacks and Mexican-Americans, personal communication.

Blake, E.T. (1994) A Worldwide Map of the $D Q \alpha$ Gene. Presented at the California Association of Criminalists Seminar, oakland, CA.

Blake, E., Mihalovich, J., Higuchi, R., Walsh, P.S. and H. Erlich (1992) Polymerase Chain Reaction (PCR) Amplification and Human Leukocyte Antigen (HLA) $-D Q \alpha$ Oligonucleotide Typing on Biological Evidence Samples: Casework Experience. Journal of Forensic Sciences, $37(3): 700-726$.

Budowle, B. and I. Davidson (1984) The Theory and Evolution of Electrophoretic Methods. Crime Laboratory Digest, $11(3): 45-$ 50 .

Budowle, B., Lindsey, J.A., Decou, J.A., Koons, B.W., Giusti, A.M. and C.T. Comey (1995) Validation and Population studies of the LOCi LDLR, GYPA, HBGG, D7S8, and GC (PM loci), and HLA$\mathrm{DQ} \alpha$ Using a Multiplex Amplification and Typing Procedure. Journal of Forensic Sciences, $40(1): 45-54$.

Bureau of the Census, U.S. Department of Commerce (1993) We the American Asians. Available from: U.S. Government Printing office 1993:350-631.

Cavalii-sforza, L.I. and W.F. Bodmer (1971) The Genetics of Human Populations. San Francisco, W.H. Freeman and Company. 
Cetus Corporation (1990) Amplitype ${ }^{\pi N}$ User Guide, Version 2. Emeryvilie, CA.

Comey, C.T., Koons, B.W., Presley, K.W., Smerick, J.B., Sobieralski, C.A., stanley, D.M. and F.S. Baechtel (1994) DNA Extraction strategies for Amplified Fragment Length Polymorphism Analysis. Journal of Forensic science, $39(5): 1254-1269$.

Comey, C.T. and B. Budowle (1991) Validation Studies on the Analysis of the HIA DQ $\alpha$ Locus Using the Polymerase Chain Reaction. Journal of Forensic Sciences, 36(6):1633-1648.

Crow, J.F. (1986) Basic Concepts in Population, Quantitative, and Evolutionary Genetics. New York, W.H. Freeman and Company .

Darlu, P. and L.I. Cavalli-Sforza (1985) The Probability of Exclusion of Ancestries Based on Genetic Observations. American Journal of Human Genetics, 37:581-590.

De Forest, P.R., Gaensslen, R.E. and H.C. Lee (1983) Forensic Science: An Introduction to Criminalistics. New York, McGrawHill.

Denault, G.C., Takimoto, H.H., Kwan, Q.X. and A. Pallos (1980) Detectability of Selected Genetic Markers in Dried Blood on Aging. Journal of Forensic Science, 25(3):479-498.

Divall, G.B. (1985) The application of electrophoretic techniques in the field of criminology. Electrophoresis, $6(6): 249-300$.

Dykes, D.D. (1982) The Use of Frequency Tables in Parentage Testing. Probability of Inclusion in Paternity Testing: A Technical Workshop, Arlington, Virginia, American Association of Blood Banks.

Fisher, D.L., Holland, M.M., Mitchell, L., Sledzik, P.S., Wilcox, A.W., Wadhams, M. and V.W. Weedn (1993) Extraction, Evaluation, and Amplification of DNA from Decalcified and Undecalcified United States civil War Bone. Journal of Forensic Sciences, $38(1): 60-68$.

Gaensslen, R.E. (1983) Sourcebook in Forensic Serology, Immunology, and Biochemistry. Washington, D.C., U.S. Government Printing office. 
Gaensslen, R.E. (1985) When Blood Is Their Argument: Use and Interpretation of Population Genetic Marker Frequency Data in Forensic Serology. Crime Laboratory Digest, 12(4):75-81.

Gaensslen, R.E., S.C. Bell and H.C. Lee (1987a) Distributions of Genetic Markers in United States Populations: I. Blood Group and secretor Systems. Journal of Forensic Sciences, $32(4): 1016-1058$.

Gaensslen, R.E., S.C. Bell and H.C. Lee (1987b) Distributions of Genetic Markers in United States Populations: II. Isoenzyme Systems. Journal of Forensic Sciences, $32(5): 1348-1381$.

Gaensslen, R.E., S.C. Bell and H.C. Lee (1987C) Distributions of Genetic Markers in United States Populations: III. Serum Group Systems and Hemoglobin Variants. Journal of Forensic Sciences, $32(6): 1754-1774$.

Gaensslen, R.E. and H.C. Lee (1990) Genetic Markers in Human Bone Tissue. Forensic Science Review, 2(2):125-146.

Grunbaum, B.W., S. Selvin, B.A. Myhre and N. Pace (1980) Distribution of Gene Frequencies and Discrimination Probabilities for 22 Human Blood Genetic systems in Four Racial Groups. Journal of Forensic Sciences, $25(2): 428-444$.

Guo, S.W. and E.A. Thompson (1992) Performing the Exact Test of Hardy-Weinberg Proportion for Multiple Alleles. Biometrics, $48: 361-372$.

Harris, H. and D.A. Hopkinson (1976) Handbook of Enzyme Electrophoresis in Human Genetics. Amsterdam, North-Holland Publishing Company.

Hartl, D.L. (1988) A Primer of Population Genetics (2nd ed.) Sunderland, Massachusetts, Sinauer Associates.

Helmuth, R., Fildes, N., Blake, E., Luce, M.C., Chimera, J., Madej, R., Gorodezky, C., Stoneking, M., Schmill, N., Klitz, W., Higuchi, R. and H.A. Erlich (1990) HLA-DQ $\alpha$ Allele and Genotype Frequencies in Various Human Populations, Determined by Using Enzymatic Amplification and oligonucleotide Probes. American Journal of Human Genetics, 47:515-523.

Hernandez, J.L., Elsto.,, R.C. and I.J. Ward (1990) Gametic equilibrium between 24 polymorphic markers. Human Genetics, $85: 343-348$. 
Herrin, G., Fildes, N. and R. Reynolds (1994) Evaluation of the AmpliType PM DNA Test System on Forensic Case Samples. Journal of Forensic Sciences, $39(5): 1247-1253$.

Higuchi, R., von Beroldingen, C.H., Sensabaugh, G.F. and H.A. Erlich (1988) DNA typing from single hairs. Nature, 332:543546 .

Hochmeister, M.N., Budowle, B., Borer, U.V., Eggmann, U.,' Comey, C.T. and R. 'Dirnhofer (1991) Typing of Deoxyribonucleic Acid (DNA) Extracted from compact Bone from Human Remains. Journal of Forensic Sciences, $36(6): 1649-1661$.

Hulen, P.I. (1984) The Simultaneous Electrophoresis of Phosphoglucomutase and Peptidase A in Seminal Stains. Crime Laboratory Digest, $11(2): 33-34$.

Maiste, P.J. (1993) Comparison of statistical tests for independence at genetic loci with many alleles. PhD dissertation, North Carolina State University.

Mckusick, V.A. (1980) The anatomy of the human genome. Journal of Heredity, 71:370-391.

Mourant, A.E., Kopec, A.C. and K. Domaniewska-Sobczak (1976) The Distribution of the Human Blood Groups and other Polymorphisms (2nd ed.) London, oxford University Press.

Nakamura, Y., Leppert, M., O'Connell, P., Wolff, R. Holm, T., Culver, M. , Martin, C., Fújimoto, E., Hoff, M. Kumlin, E. and R. White (1987) Variable Number of Tandem Repeat (VNTR) Markers for Human Gene Mapping. Science, 235:1616-1622.

Newall, P. (1985) Determination of the Antigens of the HLA System in Bloodstains. Advances in Forensic Science (Lee, H.C. and R.E. Gaensslen, eds.), Foster City, California, Biomedical Publications.

o'Brien, S.J., ed. (1993) Genetic Maps: Locus Maps of Complex Genomes. Cold Spring Harbor, New York, Cold Spring Harbor Laboratory Press.

Paabo, S. (1989) Ancient DNA: Extraction, characterization, molecular cloning, and enzymatic amplification. Proceedings of the National Academy of Sciences USA, 86:1939-1943.

Race, R.R. and R. Sanger (1975) Blood Groups in Man (6th ed.) oxford, Blackwell Scientific Publications. 
Reynolds, R., von Beroldingen, C. and G.F. Sensabaugh (1989) Effects of DNA Degradation on Amplification by the Polymerase Chain Reaction, in Proceedings of the International symposium on the Forensic Aspects of DNA Analysis. Washington, D.C., U.S. Government Printing office, p. 257.

Reynolds, R., Sensabaugh, G. and E. Blake (1991) Analysis of Genetic Markers in Forensic DNA Samples Using the Polymerase Chain Reaction. Analytical Chemistry, 63(1):2-15.

Rothwell, N.V. (1979) Understanding Genetics (2nd ed.) New York, oxford University Press.

Roychoudhury, A.K. and M. Nej (1988) Human Polymorphic Genes World Distribution. New York, Oxford University Press.

Salazar, M., Williamson, J. and D.H. Bing (1994) Genetic Typing of the DQA*4 Alleles by Restriction Enzyme Digestion of the PCR Product obtained with the DQ Alpha Amplitype Kit. Journal of Forensic Sciences, $39(2): 518-525$.

Sambrook, J., Fritsch, E.F. and T. Maniatis (1989) Molecular Cloning: A Laboratory Manual. Cold Spring Harbor, New York, Cold Spring Harbor Laboratory Press.

Schneider, P.M., Veit, A. and C. Rittner (1991) PCR-Typing of the Human HLA-DQ $\alpha$ Locus: Population Genetics and Application in Forensic Casework. DNA-Technology and Its Forensic Application, Berlin, Springer-Verlag, pp. 85-91.

Sokal, R.R. and F.J. Rohlf (1981) Biometry: The principles and practice of statistics in biological research (2nd ed). San Francisco, W.H. Freeman and Company.

Suzuki, D.T., A.J.F. Griffiths, J.H. Miller and R.C. Lewontin (1989) An Introduction to Genetic Analysis (4th ed.). New York, W.H. Freeman and Company.

Weir, B.S. (1990) Genetic Data Analysis. Sunderland, Massachusetts, Sinauer Assor tes.

Weir, B.S. (1994a) Tests ror Disequilibrium in Roche Databases: Oakland Black Data, personal communication.

Weir, B.S. (1994b) Tests for Disequilibrium in Roche Databases: Santa Clara Databases, personal communication. 